\title{
Market discipline at German savings banks
}

\author{
Andreas Pfingsten* \\ University of Münster
}

\author{
Norbert Sträter** \\ University of Münster
}

\author{
Daniel Wissing*** \\ University of Münster
}

September 4, 2008

$\ddagger \quad$ Using the BankScope data base was made possible by a generous grant from the Sparda-Bank Münster eG. For helpful comments on earlier versions of this paper, we are indebted to Andrea Schertler and Mark Trede, as well as to participants of the HypoVereinsbank PhD workshop in Kiel, the Finance Research Seminar in Münster, and the Econometrics Research Seminar in Münster. Not having incorporated all suggestions in the present work is our own responsibility, as are remaining errors and omissions.

* Finance Center Münster, University of Münster, Universitätsstr. 14-16, 48143 Münster, Germany, andreas.pfingsten@wiwi.uni-muenster.de

** Finance Center Münster, University of Münster, Universitätsstr. 14-16, 48143 Münster, Germany, norbert.straeter@wiwi.uni-muenster.de

*** Corresponding author, Finance Center Münster, University of Münster, Universitätsstr. 14-16, 48143 Münster, Germany, daniel.wissing@wiwi.uni-muenster.de 


\section{Abstract}

Several theoretical studies suggest that only uninsured depositors have an incentive to discipline their banks, i.e. react with changes in deposit volumes or in required interest rates as a reaction to changes in banks' risk. This paper empirically investigates whether German savings banks are disciplined by their depositors although these should be regarded as fully insured due to public guarantees. Using accounting data for the years 1998 through 2005 we analyze whether the withdrawal behavior and the required risk premia change as predicted by the theory. We find that insured depositors, too, discipline banks by demanding higher interest rates and, to a moderate extent, by withdrawing their deposits. Thus, depositors apparently exert market discipline even when they are fully insured against losses.

Key Words: Banking regulation, market discipline, deposit insurance, savings banks, Germany.

JEL Classification: G21, G28 


\section{Introduction}

Depository institutions are exposed to the threat of a bank run (Diamond and Dybvig (1983)). Since this also damages the economy, various systems of deposit insurance were established around the globe (Demirgüç-Kunt and Kane (2002), Demirgüç-Kunt et al. (2005)). They increase financial stability but unfortunately also reduce depositors' incentives to monitor the banks. In particular fully insured depositors may not have any incentive to exert market discipline, i. e. penalize banks for poor performance or excessive risk taking by withdrawing their money or requiring higher interest rates. ${ }^{1}$

Unlike uninsured depositors, fully insured depositors do not suffer at all from the losses of a bank failure (Merton (1977)). Thus, a deposit insurance scheme with an unlimited coverage may completely eliminate market discipline and banks may take over higher unobservable risks (Boot and Greenbaum (1993)). However, if public guarantees are not credible or merely limited, even insured depositors may react in response to banks' excessive risk taking behavior (Cook and Spellman (1996)).

But do insured depositors really put aside market discipline altogether? It is surprising that there is hardly any empirical work on this issue and the few exceptions yield differing results. Considering partial contradictions between theoretical and empirical studies, the main objective of our paper is to answer the following questions:

1. Do fully insured depositors exert market discipline by requesting higher risk premia from riskier banks?

2. Do fully insured depositors exert market discipline by withdrawing their deposits from riskier banks?

Among the reasons for some lack of empirical research in this area is the absence of suitable institutional settings. Large numbers of banks with fully insured depositors are not easily found.

1 In general, market discipline describes the notion that market forces punish banks' excessive risk taking (Berger (1991)). 
We will therefore shed light on the above questions by analyzing the depositors' behavior of German savings banks for the years 1998 through 2005. In doing so, this paper contributes to the growing literature that investigates empirically the effects of deposit insurance on market discipline and extends it into two directions. Firstly, to the best of our knowledge, there is currently just one empirical study on the role of market discipline in Germany. Gräbener (2008) examines whether bond holders of 66 large banks exerted market discipline by requesting higher risk premia during 2000-2004. Apart from this, the German banking market has only briefly been touched in some cross-country studies. ${ }^{2}$ Secondly, we evaluate the interaction between market discipline and a special form of deposit insurance, namely the institutional assistance scheme. This system, which will be explained in more detail later, allows basically only fully insured deposits, an issue which so far has been largely unexplored in the literature on market discipline.

We provide evidence for market discipline at German savings banks, i. e. even insured depositors discipline riskier banks by demanding higher interest rates. To a lesser extent our results indicate that insured depositors discipline riskier banks by withdrawing their deposits. We conclude that deposit insurance does not appear to eliminate market discipline completely, i. e. depositors exert market discipline even when they are fully insured against losses. One tentative explanation for these results is that insured depositors are aware of the costs that are associated with the recovery of deposits after a bank failure and hence have an incentive to monitor their banks. ${ }^{3}$ Another explanation may be that the insured depositors do not know that they are fully insured and therefore still have an interest in monitoring the safety of their deposits. ${ }^{4}$ And finally, it may as well be that they simply do not trust the guarantees provided or the solvency of the institutional assistance scheme.

2 This may be due to the German accounting rules ("HGB") with their emphasis on creditor protection and capital maintenance (instead of fair value accounting) which makes comparisons difficult. Additionally the existence of three independent deposit insurance systems within the German banking sector makes it somewhat intransparent.

3 However, this reasoning does not work for German savings bank. Due to the institutional assistance scheme, no bank failure occurs because eventually a troubled savings bank is, e.g., merged with a neighboring institution. With hardly any effort required from the depositors, their funds are shifted to the new institution.

4 Preliminary results of an ongoing study indicate that this may indeed be the case. 
The remainder of the paper is structured as follows. In Section 2 we put our paper in perspective to the existing literature in this area in more detail and present a brief description of the German banking system and its deposit insurance schemes. Section 3 describes our empirical methodology. Section 4 discusses our data set and our choice of variables. Section 5 contains our main findings. Finally, Section 6 draws some conclusions and discusses directions for further research.

\section{Background of Our Study}

\section{$2.1 \quad$ Related Literature}

The majority of empirical studies conducted to investigate market discipline looks at uninsured deposits or subordinated debt as sources of market discipline. They mainly focus on the question whether market discipline by these kinds of depositors existed during a certain period of time. Most of the studies support the hypothesis that market discipline is at work and banks are punished for excessive risk taking. Seminal contributions include Baer and Brewer (1986), Ellis and Flannery (1992), Park (1995), Park and Peristiani (1998), Martinez Peria and Schmukler (2001), Maechler and McDill (2006) or Ioannidou and de Dreu (2006). The studies can be further divided into those that control for yields and those that control for the level of deposits in relation to banks' risk taking. In our study we will do both.

Most of the literature on the efficiency of market discipline refers to the U.S. and the Japanese banking systems. Concerning the similarities of the deposit insurance systems and countryspecific similarities, there are two studies which are closely related to our study. Birchler and Maechler (2002) examine whether uninsured depositors exert market discipline in a sample of Swiss banks during 1987-1998. It is one of the few studies which explicitly look at an European banking market. Furthermore some of the banks in their study are cantonal banks which benefit from a state guarantee. The authors find evidence that depositors of cantonal banks seem to be less risk sensitive. Gräbener (2008) tests whether bond holders of 66 large German banks 
discipline the risk taking behavior by banks. He finds evidence that the risk premia of traded bonds are related to banks' ratings.

Cross-country studies show that explicit deposit insurance reduces market discipline exerted by depositors (Demirgüç-Kunt and Huizinga (2004)) and that it thereby increases the probability of financial crises (Demirgüç-Kunt and Kane (2003)). Good surveys of the international literature are compiled by Gilbert (1990), Flannery (1998), Board of Governors of the Federal Reserve System and U.S. Department of the Treasury (2000), Basel Committee on Banking Supervision (2003), Frolov (2004), and Kobayashi and Bremer (2007).

At the same time, insured depositors receive less attention due to the conjecture that they have no incentive to monitor their banks, withdraw their money, or require adequate risk premia. In line with this supposition, several studies indicate that there is a direct link between market discipline of depositors and their insurance level. Hovakimian et al. (2003) provide crosscountry evidence that an explicit deposit insurance may encourage banks to increase risk and that this can be mitigated by setting an adequate deposit insurance framework. DemirgüçKunt and Huizinga (2004) find cross-country evidence which suggests that explicit deposit insurance reduces interest rates and at the same time lowers market discipline on banks' risk taking behavior. Depositors are less sensitive to banks' risks if they are better protected. Ioannidou and de Dreu (2006) derive similar conclusions. They investigate market discipline for a Bolivian dataset and show that at a coverage rate of more than 60 percent, market discipline is significantly reduced and it is completely eliminated when the coverage rate reaches 100 percent.

Nevertheless, recently some studies have challenged the traditional view by providing evidence that also fully insured depositors may still exert market discipline. Cook and Spellman (1996) find evidence that rates of insured deposits are related to banks' risk and guarantors' risk. An increased risk perception of the bank, but also a decline in the perceived government guarantor credit quality, led to increased interest premia of insured deposits. Park and Peristiani (1998) investigate in their study whether riskier thrifts have to pay higher interest rates and can only attract smaller amounts of deposits. Their results on uninsured and insured deposits indicate that also holders of fully insured deposits (small Certificates of Deposits) exert market 
discipline. Davenport and McDill (2006) analyze depositor behavior at a failed institution. One important result is that the vast majority of deposits withdrawn were fully insured by public guarantees. Fueda and Konishi (2007) analyze depositors' responses to banks' risk under different deposit insurance regimes. They find evidence that market discipline is most significantly exerted during periods of full insurance coverage. The study of Martinez Peria and Schmukler (2001) is the one most closely related to our work concerning the methodology. ${ }^{5}$ They investigate whether depositors in Argentina, Chile, and Mexico discipline their banks for excessive risk taking. Even for insured depositors they show that these depositors penalize banks by withdrawing their deposits. The results listed in this paragraph seem to be astonishing because theory assumes that insured depositors do not react to banks' increased risk taking due to the insurance cover. However, if depositors are still afraid of loosing their deposits, justified or not, they may react in response to banks' excessive risk taking behavior. Based on the contradictory empirical results, further research is essential.

The German banking system, little explored with respect to deposit insurance, is an interesting arena for a further examination. Up to 2005, depositors of a whole group of banks, the savings banks, were fully insured because these banks were endowed with basically unlimited government guarantees. Since our analysis later on requires some knowledge of the German banking system to appreciate our findings, we devote the next section to a description of its most important features.

\subsection{Germany's Three-Pillar Banking System}

The German banking sector is composed of three main pillars: the credit cooperatives, the savings banks, and the commercial banks. As part of an universal banking system, all of them offer a broad range of similar activities. The savings banks are owned by different groups of jurisdictions (e.g. communities, cities, or states), whereas credit cooperatives and commercial banks are owned privately. Because of their public ownership, savings banks are obliged to

$5 \quad$ Their methodology is in our opinion currently the most convincing one and furthermore well suited for our data. We will describe the modeling approach in detail in Section 3. 
serve public interest in their region. Savings banks, as well as credit cooperatives, are set up as a two-tier system. The local banks are usually confined to operate in local markets which normally do not overlap. The few affiliated central institutions mainly offer services that cannot be supplied efficiently by small local banks themselves due to lack of competence or (efficient) size (Koetter et al. (2006)). The commercial banking sector consists of three distinct groups: a few big banks, ${ }^{6}$ regional banks (with the group of private bankers included) and the branches of foreign banks.

\section{Size Distribution}

Concerning the number of about 2,000 monetary financial institutions ${ }^{7}$ the savings banks and the cooperatives clearly dominate the German market, as can be seen in Figure 1. Although a lot of mergers, especially among credit cooperatives, took place in the last years, the structure is rather fragmented. ${ }^{8}$ In rural areas the cooperatives often only compete with savings banks because commercial banks are commonly focussed on more densely populated areas.

If measured by the sum of total assets, the dominance of the credit cooperatives does not persist (see Figure 2). Throughout the whole observation period, the group of savings banks represents the largest banking pillar with, for example, total assets of nearly 2,500 billion EUR in 2006, $50 \%$ being held by the twelve central savings banks called Landesbanken. The sizes of local savings banks are quite different. Each of the ten largest ones holds total assets of more than 10 billion EUR in 2006, whereas the majority is of small and medium size. This results in a median of 1.4 billion EUR which is smaller than the arithmetic mean of 2.2 billion EUR (Moormann and Schnitzler (2007)). The commercial banks are the second largest and fastest growing group, with the big banks alone accounting for more than 50 percent of this pillar. Credit cooperatives are still characterized by their small size, although the arithmetic mean

6 Currently Deutsche Bank AG, Dresdner Bank AG, Commerzbank AG, Bayerische Hypo- und Vereinsbank AG, Deutsche Postbank AG.

7 The number of financial institutions decreased from 3,414 to 2,048 (40\%) between December 1997 and December 2006. Figure 1 does not include about 60 specialized institutions, namely real estate banks, building societies, and special purpose banks because of their minor relevance for our research questions.

8 There exist almost no mergers across the three pillars. 


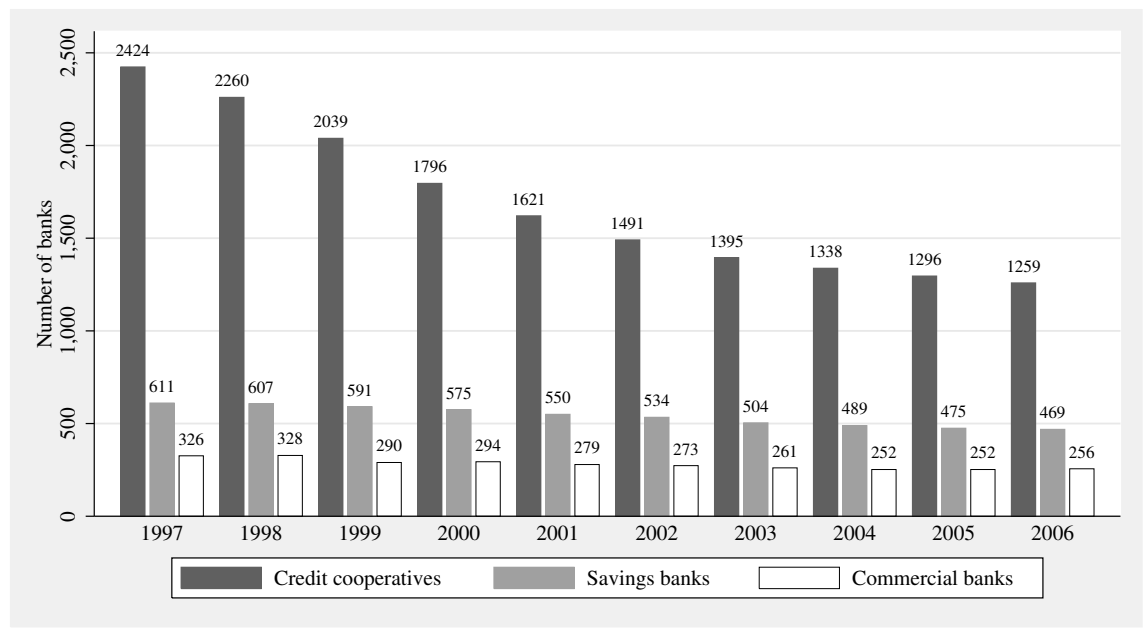

Figure 1: Number of banks in each pillar (end of year)

Source: Deutsche Bundesbank (2007d).

of total assets increased from 0.3 billion EUR to 0.7 billion EUR during 1997-2006. In 2006, the median of total assets is still lower than 0.25 billion EUR for credit cooperatives. Since the German Banking system consists of a fair number of small, medium, and large banks with different structures and constraints, an investigation of market discipline controlling for bank size appears to be promising for Germany.

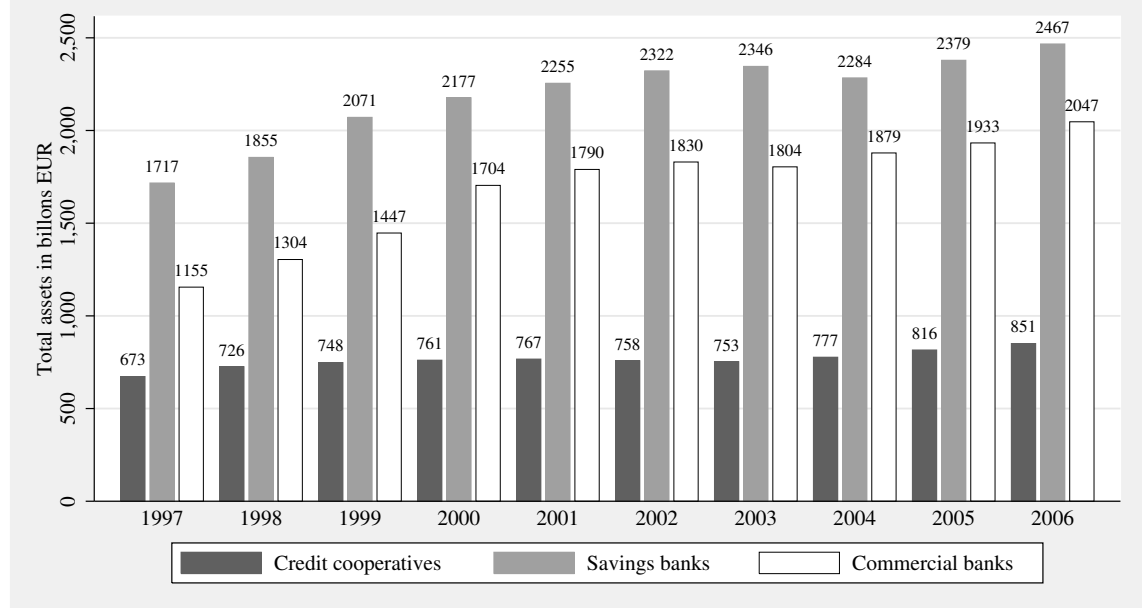

Figure 2: Total assets in each pillar (end of year)

Source: Deutsche Bundesbank (2007b). 


\section{Liability Structure}

The liability structure of German banks is remarkably different across the three banking pillars. Local credit cooperatives and savings banks are able to attract customer deposits for about two thirds of their total assets as shown in Figure 3 for 2006. This is achieved by a large number of branches and due to less competition often prevailing in rural areas. Bank deposits are, often from their central institutions, the second most important source of funds for those institutions. They use securitized liabilities, subordinated debt and participation rights only to a minor extent.

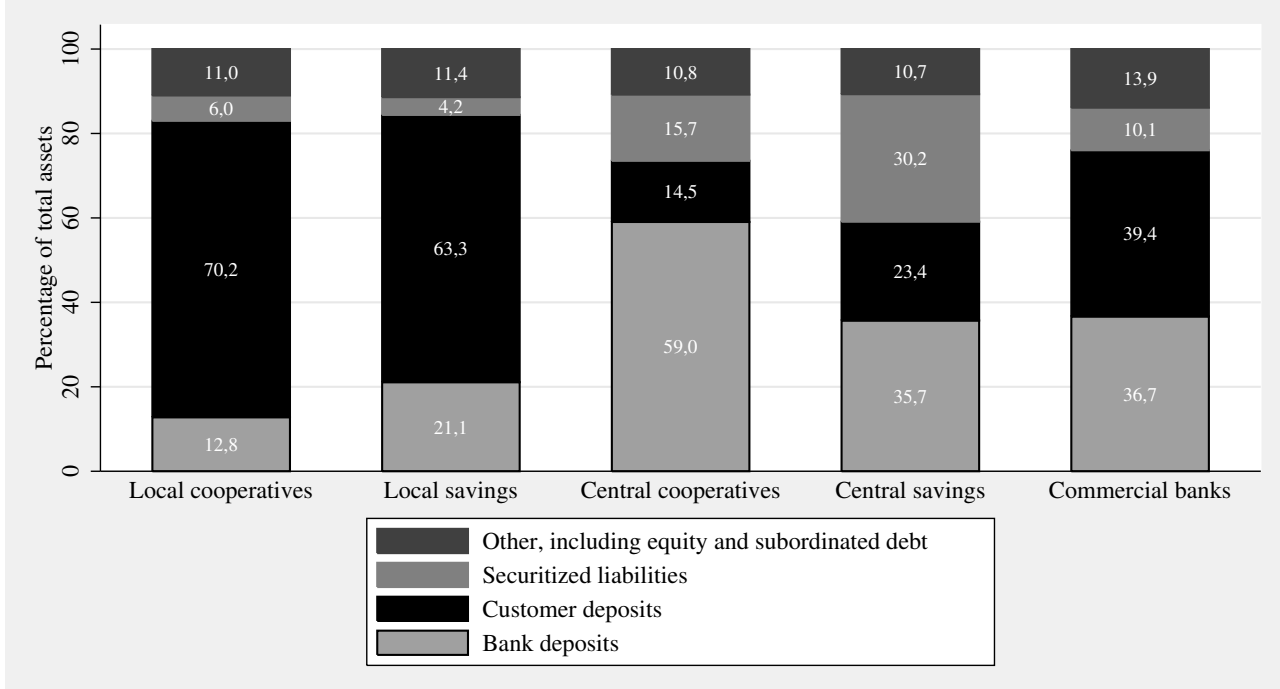

Figure 3: Liability compositions of selected banking groups (end of 2006)

Source: Deutsche Bundesbank (2007a), pp. 10-13.

The liability structure of the central institutions of cooperative and of savings banks is not as similar. Central savings banks ("Landesbanken") have securitized liabilities and bank deposits in relatively equal shares as their most important sources of funding. Central cooperatives refund their business mostly through bank deposits. ${ }^{9}$ The liability structure reflects the twotier system of those pillars (Koetter et al. (2006)). The locally acting banks use their sound customer base for attracting deposits from households, whereas the central banks employ their size and reputation for other sources of funding. Finally, commercial banks usually either

9 The customer deposits of the central institutions of savings and of cooperative banks are mainly time deposits of corporate firms. 
attract customer deposits in densely populated areas or use the interbank market. However, they also make use of a considerable amount of securitized liabilities (roughly 10 percent).

\section{German Reunification}

The German separation after the Second World War led to a different development of the banking systems in the market-oriented western and the socialistic eastern parts of Germany. Especially the eastern system changed. The savings banks, for example, were temporarily closed and their assets transferred to the federal government. Reopened, local independence was increasingly replaced with centralism (Wysocki and Günther (1996)). During the reunification in 1989/1990, the East German savings banks were resolved - with the aid of West German savings banks - from the state bank and were reintegrated into the German savings bank organization (Günther (2006)). Up to now, the eastern parts of Germany are characterized by weaker macroeconomic constitutions, provoking in the interesting question whether savings banks in the eastern parts of Germany are disciplined to a higher or lower level than the ones in the western parts.

\section{Deposit Insurance}

Each of the three pillars of the German banking system has its own deposit insurance system. In addition to the compulsory system which is based on the European directive 94/19/EC on deposit-guarantee schemes and came into force in 1998, the commercial banks have established a voluntary system that is used to provide further protection since the statutory scheme may only provide a basic coverage. It is non-obligatory, but nearly all banks participate. As commercial banks are in direct competition with each other, the main purpose of the deposit scheme is to guarantee the availability of insured deposits and not the bail-out of a bankrupt institute. The deposit insurance systems of savings banks and cooperative banks with their apex institutions are systems based on the solidarity of their member institutions. Their primary task is maintaining the liquidity and solvency of all banks embodied. Membership in these schemes is not voluntary and as the survival of the banks is guaranteed, depositors virtually enjoy unlimited protection. Additionally, until July 2005, the savings banks enjoyed explicit 
deposit guarantees provided by their local authorities, namely Gewährträgerhaftung (guarantee obligation) and Anstaltslast (maintenance obligation). ${ }^{10}$ The Gewährträgerhaftung made the local authority liable against others without restriction if their savings bank went bankrupt. Through the Anstaltslast local authorities were obliged to capitalize their savings banks adequately, because they were responsible for the viability of the company. To sum up, until 2005 all depositors of German savings banks benefited from the institutional assistance scheme and from associated government guarantees so that practically all of their liabilities must be viewed as fully covered.

\section{Methodology}

To check market discipline through depositors, we only focus on information that is typically available for ordinary depositors. Therefore, we concentrate on publicly available bank-level data from financial statements. During the period of our study, the German financial system experienced no changes in the deposit insurance scheme. In accordance with the empirical literature which examines market discipline, we measure the reaction of the interest rates and the deposit growth rates to banks' risk taking by two reduced form equations. ${ }^{11}$ Like Martinez Peria and Schmukler (2001), we test for each model separately whether bank risk measures can significantly explain the dependent bank-level variable. The general reduced forms used are as follows:

$$
\begin{aligned}
\text { InterestRate }_{i, t} & =\beta_{1} \cdot \text { BankRisk }_{i, t-1}+\alpha_{i}+\lambda_{t}+\varepsilon_{i, t} \\
\text { DepositGrowth }_{i, t} & =\beta_{2} \cdot \text { BankRisk }_{i, t-1}+\alpha_{i}+\lambda_{t}+\omega_{i, t}
\end{aligned}
$$

where $i=1, \ldots, N$ and $t=1, \ldots, T . N$ is the number of banks and $T$ is the bank-specific number of observations, because we use an unbalanced panel. InterestRate $_{i, t}$ is the average interest

10 See e.g. Hackethal (2004).

11 Ideally one should estimate simultaneous equations models to specify the demand and supply equations of deposits. The problem is that these data cannot easily be observed and therefore reduced-form equations are typically used. For an intuitive discussion of this topic see e.g. Park (1995) and Ioannidou and de Dreu (2006). 
rate paid on deposits in bank $i$ in period $t$ and DepositGrowt $h_{i, t}$ represents the growth rate of deposits in bank $i$ in period $t$. We use the growth rate of deposits instead of its level to avoid nonstationarity. The vector of publicly available bank risk characteristics, BankRisk $k_{i, t-1}$, is described extensively in the next section. We include a lag of one year in the vector of banks' risk taking behavior to take into account that general accounting data is publicly available merely with a delay. This holds especially true for German savings banks. They are not subject to strict quarterly publication rules as are, for example, incorporated banks.

Combined entity and time fixed panel regression models are estimated where $\alpha_{i}$ represents the entity (bank) fixed effect and $\lambda_{t}$ is the time fixed effect. The models eliminate the omitted variable bias arising both from unobserved/unmeasured variables that are constant over time but vary across entities (especially regional differences across locally acting savings banks) and from unobserved variables that are constant across entities but vary over time (especially general macroeconomic and banking sector developments). We estimate heteroskedasticity- and autocorrelation-consistent (called HAC or clustered) standard errors, because they are valid if the error terms $\varepsilon_{i, t}$ and $\omega_{i, t}$ are potentially heteroskedastic and potentially correlated over time within an entity. ${ }^{12}$

In order to test whether insured depositors exert market discipline by requesting higher interest rates from riskier banks, we should be able to reject the null hypothesis of $\beta_{1}=0$. This means the individual or joint estimates of $\beta_{1}$ are statistically significant different from zero. In other words, the interest rates are correlated with the banks' risk indicators. Furthermore, insured depositors could exert market discipline by withdrawing deposits when observing weak bank risk characteristics. Accordingly, we should be able to reject the null hypothesis of $\beta_{2}=0$, i.e. the growth rates of deposits are correlated with the banks' fundamentals. The examination of both dependent variables provides a better test of market discipline than just looking at one of them, although we cannot easily model the interaction of interest rates and deposit growth.

12 Clustered standard errors allow the errors to be correlated within a group, but assume that they are uncorrelated for errors not in the same cluster. They are designed especially for panels with small $T$ and large $N$. See e.g. Stock and Watson (2007) for further information. 
There may be an ambiguous causality between these two variables, resulting in a simultaneous causality bias and therefore biased and inconsistent estimators. ${ }^{13}$

We report fixed effects (within) estimations including results of the tested null hypothesis whether the individual or the joint estimates of $\beta_{1}$ and $\beta_{2}$ are equal to zero. Complementary, results of the F-Test of jointly significant time effects are reported. We used Intercooled Stata 9.2 for our estimations.

\section{Data}

\subsection{Data Base}

We extract annual bank-level data from 1998 to 2005 from the BankScope data base. This data base is offered by Bureau van Dijk Electronic Publishing (BvDEP), whose main information provider is Fitch Ratings. Our download contains more than 200 variables from the available "raw data"-format and includes all positions from the balance sheets and the income statements. We concentrate on unconsolidated statements of local savings banks to ensure comparability. ${ }^{14}$ Nearly all savings banks report their statements in accordance with the German Commercial Code (HGB) and just a few banks publish a consolidated statement in addition to a compulsory, unconsolidated one.

Our original unbalanced panel data set consists of 4,067 financial statements from 596 banks. We encountered 135 mergers and decided to keep the two (or sometimes more) pre-merger banks separate from the merged bank because of three main reasons: First, jumps in the bank-level time series are eliminated. Second, none of the financial statements used in our

13 See Stock and Watson (2007), pp. 324-325. Up to now, we have not made use of instrumental variable regressions as a potential solution to estimate the causal effects since well identifying instruments are in practice hardly found.

14 The few central savings banks are not included in this investigation. The central savings banks are much larger, offer different services to their customers, and unlike most local savings banks operate in international capital and interbank markets. We will take them into account when examining large commercial banks in further research. 
data set is artificial, because pre-merger statements are not combined. Third, information losses of individual bank data are minimized. However, since we need a minimum number of observations for each entity to include it in a fixed effects regression, we lose some entities for our estimations.

Next, we checked the quality of the available financial statements extensively. Starting-points were, for example, incomplete statements and negative entries (nearly all of the BankScope variables have a range of values from zero upwards). We also inspected a few missing values of commonly-used variables (e.g. interest rates, total assets, wages, and net income). Afterwards, we reconfirmed total assets, total liabilities, and the net profit by comparing the aggregated single items with the reported amount. Finally, we looked at single observations when we found unusual growth rates of variables. Overall, we dropped 89 observations including 6 complete bank histories, so that our final data set consists of 3,978 observations from 590 banks (cf. Table 1). Because of the separation of the banks when a merger took place, the number of 682 entities is higher than the number of banks in any given year. Our data set covers more than $90 \%$ of the German savings banks for each year, measured both by the number of banks and the sum of total assets (not reported here).

\begin{tabular}{cccccc}
\hline & Existing & \multicolumn{4}{c}{ Data set } \\
\cline { 3 - 5 } Year & Freq. & Freq. & Coverage & Percent & Cum. \\
\hline 1998 & 594 & 568 & $95.62 \%$ & 14.28 & 14.28 \\
1999 & 578 & 554 & $95.85 \%$ & 13.93 & 28.31 \\
2000 & 562 & 534 & $95.01 \%$ & 13.42 & 41.63 \\
2001 & 537 & 506 & $94.22 \%$ & 12.72 & 54.35 \\
2002 & 519 & 480 & $92.49 \%$ & 12.07 & 66.42 \\
2003 & 489 & 464 & $94.88 \%$ & 11.66 & 78.08 \\
2004 & 477 & 449 & $94.13 \%$ & 11.29 & 89.37 \\
2005 & 463 & 423 & $91.36 \%$ & 10.63 & 100.00 \\
\hline Total & 4,219 & 3,978 & $94.29 \%$ & 100.00 & \\
\hline
\end{tabular}

Table 1: Number of banks by year in the final data set

The data set was also divided into different groups to check, on the one hand, the robustness of the benchmark results and to focus, on the other hand, more on some important features of the German banking system as described in Section 2.2. In particular, we created a smaller balanced data set including 330 entities for eight years. ${ }^{15}$ Note that, because of the chosen

15 Cf. Table 5 (Appendix A.1) for another overview of the distribution of the observations, sorted by the number of observations for each entity. 
merger strategy, none of these institutions was involved in a merger between 1998 and 2005. Furthermore we compared, historically motivated, the results for West and East Germany. Finally, we divided large and small institutions, the latter with total assets lower than 1.5 billion EUR, to investigate the influence of bank size on the dependent variables.

\subsection{Variables}

\section{Dependent Variables}

The implicit interest rate (irate) as our first dependent variable is precisely defined as the fraction of total interest expenditure to the sum of all interest bearing liabilities of a bank $i$ at time $t$.

$$
{\text { Interest } \text { Rat }_{i, t}}=\left(\frac{\text { interest expenditure }_{i, t}}{\text { interest bearing liabilities }_{i, t}}\right)
$$

The interest bearing liabilities of German savings banks typically consist of bank deposits and customer deposits, securitized liabilities, subordinated debt, and participation rights. Income statements following HGB do not report separate interest expenditures for each group of liabilities or different initial or remaining maturities, so calculating an average rate is the only way to go. We did not use the mean of interest bearing liabilities of years $t$ and $t-1$ because this would have reduced the relatively brief history in our panel structure by one year.

Our second dependent variable, or more precisely group of variables, is the annual growth rate of deposits generally calculated as

$$
\text { DepositGrowth }_{i, t}=\left(\frac{\text { deposits }_{i, t}-\text { deposit }_{i, t-1}}{\text { deposits }_{i, t-1}}\right) \text {. }
$$

As described in the introduction, we can assume all liabilities of savings banks to be insured for the period of our study. However, it is an interesting question whether or not various groups of liabilities react differently despite equal protection. For this reason, we will measure the impact of bank risk characteristics on the growth rate of the four main components of the total interest bearing liabilities separately, namely bank deposits (bank), customer deposits 
(custom), securitized liabilities (secur), and subordinated debt (subord), and hence define the term deposits in a wider sense.

\section{Independent Variables}

The independent variables are bank characteristics related to banks' soundness. We assume that the variables that reflect the risk of a failure of a bank have negative effects on the deposit growth and positive effects on the interest expenditures. As bank fundamentals, we utilize the following variables which presumably have a close connection to the risk taking behavior of banks. Most of these lagged variables are employed in the CAMEL rating of banks (capital adequacy, asset quality, management, earnings, and liquidity). We deviate from this approach where we are convinced that adjustments according to the German accounting principles should have more explanatory power. The general structure of financial reports according to the German Commercial Code and the Ordinance on Accounting for Banks and Financial Service Companies ("RechKredV") is shown in Appendix A.2, ${ }^{16}$ followed by the exact definitions of the dependent and independent variables in Appendix A.3.

For the same reason as for the interest rates, we did not use yearly averages for the independent variables.

Capital Adequacy: The first variable, equity, is an indicator for a sound capital base. We expect that the ratio of capital to total assets has a positive influence on deposit growth and a negative influence on interest expenditures. In some other studies the risk-based capital ratio of Basel I is used, but this data is not publicly available.

Asset Quality: Often non-performing loans are considered to be a proxy for asset quality. Because of data limitations of German annual reports we instead choose the risk expenditures to total assets as the second variable, risk. Risk expenditures are about equal to the depreciations on financial assets. Banks with less risk expenditures are perceived to be safer and therefore we expect the variable to have a positive effect on deposit growth and a negative effect on interest expenditures. The third variable, real, is the ratio of real estate loans and public loans to assets.

16 The statement items used are printed in bold. 
This ratio tells us to what degree a bank is financed by loans that are highly collateralized. We expect a positive influence on deposit growth and a negative influence on interest expenditures.

Management: The forth and fifth variables, person and mater, are personnel expenditures respectively material expenses to total assets to account for management quality. These expenditures can be regarded as the quality of leadership stance for which a high level may reflect an inefficient management. However, these variables may also reflect the banks' efforts to offer intensive customer care. As German savings banks are basically limited to just one region but offer intensive market coverage and sponsorship within this region, we believe that depositors are more loyal to these banks. This allows German savings banks to collect additional deposits and offer lower interest rates than the market rate. Therefore, we expect that the variables have a positive influence on deposit growth and a negative influence on interest expenditures.

Earnings: We use the sixth variable return on assets, return, as an indicator of the current profitability of a bank. It may also be a good predictor for banks' performance and therefore strengthen depositors' confidence. We expect it to have a positive influence on deposit growth and a negative influence on interest expenditures.

Liquidity: The seventh variable, cash, is an indicator for liquidity. Depositors may fear that banks with a small volume of liquid assets have difficulties to meet unexpected deposit withdrawals and are consequently prone to bank runs. We expect that the ratio of liquidity to total assets has a positive influence on deposit growth and a negative influence on interest expenditures.

\subsection{Summary Statistics}

Table 2 shows the summary statistics of the full pooled data set. ${ }^{17}$ In addition to the number of observations we report the arithmetic mean and the standard deviation of the distributions. Further statistics are the minimum and maximum as well as the 1,50 (median) and 99 percentiles. The variables are listed in the same order in which they were introduced above.

17 Tables 6 through 10 of Appendix A.1 (starting on page 32) show the summary statistics for the sub-groups. 
The first five entries describe the dependent variables and the next seven show the bank risk characteristic variables. Furthermore, total assets are presented in billion EUR.

\begin{tabular}{rrrrrrrrr}
\hline Variable & $\mathbf{N}$ & Mean & Std. Dev. & Min & P1 & P50 & P99 & Max \\
\hline irate (\%) & 3,978 & 3.22 & 0.55 & 1.57 & 1.94 & 3.29 & 4.29 & 5.57 \\
bank (\%) & 3,296 & 4.44 & 17.17 & -65.20 & -36.16 & 2.69 & 56.57 & 163.72 \\
custom (\%) & 3,296 & 1.48 & 3.63 & -16.58 & -6.58 & 1.33 & 11.77 & 25.90 \\
secur (\%) & 2,872 & -1.62 & 110.40 & -100.00 & -100.00 & -4.29 & 128.07 & 5000.00 \\
subord (\%) & 2,770 & 2.86 & 32.07 & -100.00 & -100.00 & 0.00 & 105.48 & 473.42 \\
equity (\%) & 3,978 & 4.57 & 1.00 & 0.00 & 2.67 & 4.43 & 7.87 & 9.59 \\
risk (\%) & 3,978 & -0.50 & 0.37 & -5.39 & -1.53 & -0.48 & 0.40 & 1.44 \\
real (\%) & 3,978 & 23.90 & 7.70 & 4.48 & 6.76 & 24.33 & 41.28 & 52.82 \\
person (\%) & 3,978 & 1.26 & 0.19 & 0.53 & 0.76 & 1.26 & 1.72 & 2.28 \\
mater (\%) & 3,978 & 0.80 & 0.17 & 0.32 & 0.48 & 0.78 & 1.33 & 2.02 \\
return (\%) & 3,978 & 0.20 & 0.20 & -5.07 & 0.00 & 0.20 & 0.57 & 1.81 \\
cash (\%) & 3,978 & 2.17 & 0.87 & 0.45 & 0.82 & 2.05 & 5.00 & 17.28 \\
assets (bn EUR) & 3,978 & 1.81 & 2.52 & 0.04 & 0.17 & 1.12 & 13.09 & 32.70 \\
\hline
\end{tabular}

Table 2: Summary statistics of the final data set

First of all, we take a brief look at the irate variable. Defined as an average rate, the variable has a mean of $3.22 \%$ with a minimum of $1.57 \%$ and a maximum of $5.57 \%$. Note that the panel structure of the data set is ignored in Table 2. Hence, the annual arithmetic mean of all banks is reported in Figure 4 together with the annual arithmetic mean of the 12 month FIBOR (Frankfurt Interbank Offered Rate).

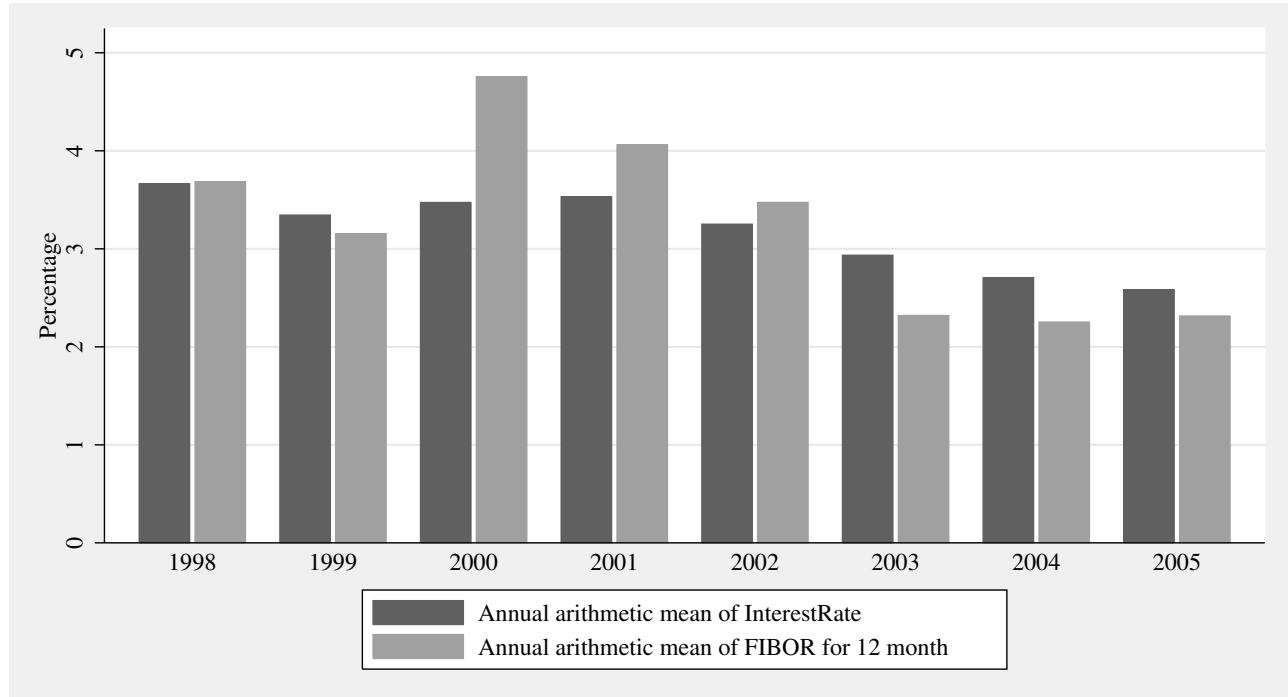

Figure 4: Comparison of InterestRate and FIBOR

Source: Deutsche Bundesbank (2007c). 
The FIBOR is more volatile than the mean of the InterestRate variable. The latter reacts on changes of the global level of interest rates with a delay. This is, any others, due to the fact that the average maturity of liabilities usually extends one year. To complete the description of the first dependent variable, a histogram is provided in Figure 6 of Appendix A.1, where the histograms of all dependent and independent variables are plotted.

The other dependent variables (growth rates of bank deposits and customer deposits, securitized liabilities, and subordinated debt) are distributed differently. As can be seen in Table 2, the mean growth rates are moderate. However, the ranges of observations are extremely varying, especially for securitized liabilities. How can this be explained? A brief look at absolute values instead of the growth rates is sufficient to easily understand the reasons. The different types of liabilities are split up in Figure 5. As indicated in Section 2.2, German savings banks have a sound customer base and therefore primarily attract deposits from households. The market share of total savings deposits administrated by savings banks amounts to more than $50 \%$. Consequently, the savings banks as a whole refinance themselves in a relatively constant manner by more than $60 \%$ via customer deposits, sometimes getting close to $90 \%$.

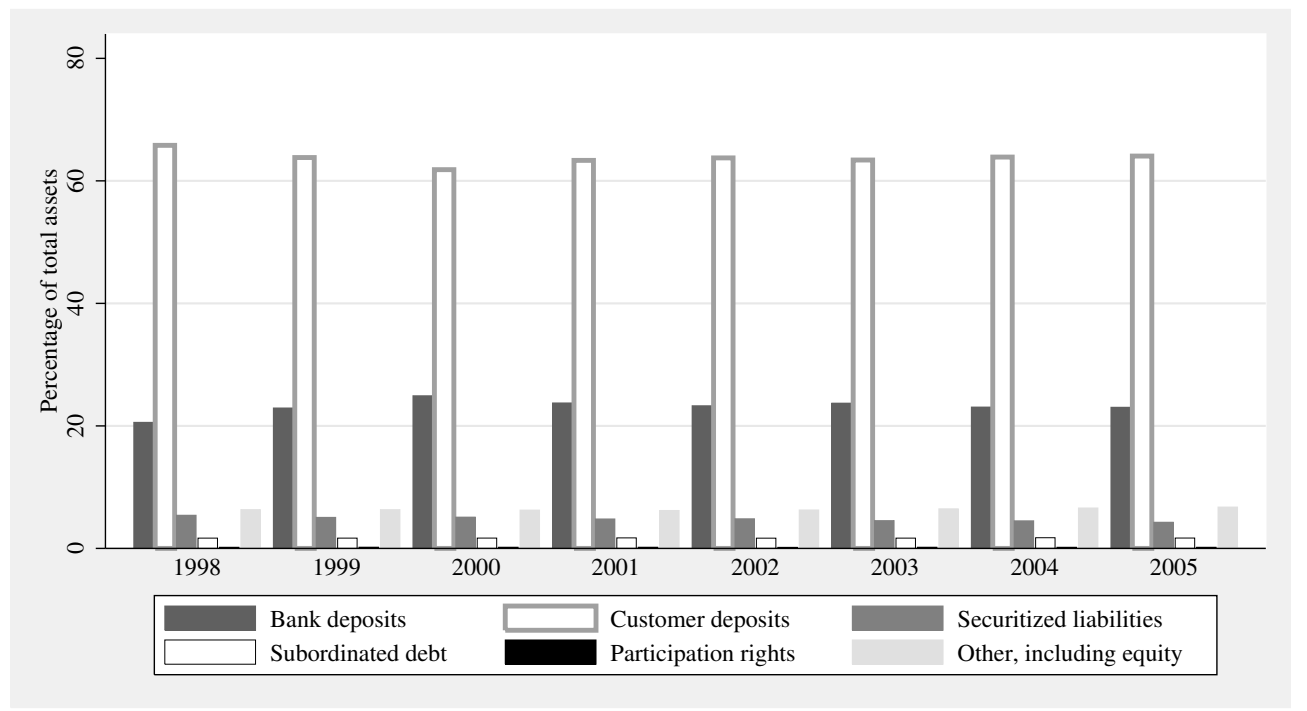

Figure 5: Shares of liabilities of all savings banks

The standard deviation of the bank deposits distribution is higher than it is for the customer deposits. Apart from just a few extreme outliers, the total values are mostly distributed between plus and minus 50\%. The histograms are collected in Figure 6 in Appendix A.1. We only exclude 
values above the 99 percentile in the histograms and in the panel regressions for securitized liabilities and subordinated debt. These distributions include high growth rates up to 5,000 percent which would have biased our results heavily. These extreme outliers can be explained by the issuing policy of securitized liabilities and subordinated debt. Savings banks usually issue them rarely (not on a regular basis, e.g., annually) and, if so, with relatively high volumes. Because of their customer deposits, savings banks do not need as much of these liabilities as, for example, incorporated banks, which issue securitized liabilities and subordinated debt more continuously.

Finally, we present the partial correlations between all dependent and the lagged independent variables in Table 3. The results are not completely consistent with our intuition. Merely the return on total assets ratio has the assumed positive sign for each category of deposits. However, the correlation between this variable and the implicit interest rate is positive instead of negative. Furthermore, the correlations among the lagged independent variables (denoted by prefix L.) and among the independent variables are almost always relatively small.

\begin{tabular}{|c|c|c|c|c|c|c|c|}
\hline & irate & bank & custom & secur & subord & L.equity & L.risk \\
\hline irate & 1.0000 & & & & & & \\
\hline bank & 0.1260 & 1.0000 & & & & & \\
\hline custom & 0.0917 & -0.1876 & 1.0000 & & & & \\
\hline secur & 0.0172 & 0.0436 & -0.0500 & 1.0000 & & & \\
\hline subord & 0.0784 & 0.0439 & -0.0200 & 0.0473 & 1.0000 & & \\
\hline L.equity & -0.0370 & -0.0360 & 0.0249 & -0.0326 & -0.0860 & 1.0000 & \\
\hline L.risk & 0.2785 & 0.2359 & -0.0365 & 0.0230 & 0.0381 & 0.0623 & 1.0000 \\
\hline L.real & 0.3713 & 0.0198 & 0.0265 & -0.0402 & -0.0215 & 0.2682 & 0.0593 \\
\hline L.person & 0.0034 & 0.0970 & -0.0833 & 0.0077 & -0.0031 & 0.2357 & 0.0951 \\
\hline L.mater & -0.3058 & -0.0187 & -0.0597 & 0.0357 & 0.0098 & -0.2471 & -0.0404 \\
\hline L.return & 0.1242 & 0.1520 & 0.1081 & 0.0104 & 0.0477 & 0.2398 & 0.4496 \\
\hline \multirow[t]{2}{*}{ L.cash } & -0.3275 & -0.1130 & -0.0150 & 0.0151 & -0.0180 & -0.0538 & -0.1197 \\
\hline & L.real & L.person & L.mater & L.return & L.cash & & \\
\hline L.real & 1.0000 & & & & & & \\
\hline L.person & 0.1271 & 1.0000 & & & & & \\
\hline L.mater & -0.3065 & 0.2769 & 1.0000 & & & & \\
\hline L.return & 0.0510 & -0.0559 & -0.1955 & 1.0000 & & & \\
\hline L.cash & -0.2279 & 0.1139 & 0.2722 & -0.0510 & 1.0000 & & \\
\hline
\end{tabular}

Table 3: Partial correlations 


\section{Results}

\subsection{Full Data Set}

Table 4 on page 28 presents our regression results for the full data set. It displays the combined entity and time fixed panel estimation results for both models presented in Section 3. In order to save space, the table merely reports the independent variables of major economic importance and does not report the time dummies. ${ }^{18}$ In the second column the table shows our results for the interest rates and in the last four columns the results for the separate growth rates of interest bearing liabilities: bank deposits, customer deposits, securitized liabilities, subordinated debt. In the following, we analyze the outcomes for the price and quantity regressions in detail and finally briefly summarize our results.

\section{Implicit Interest Rate}

In the price regression the estimated coefficient on capital to assets is negative and statistically significant (different from zero) as we expected. This indicates that banks with a higher equity base pay lower interest rates (holding the other independent variables constant). A rise in the share of real estate loans and public loans also has the supposed significant negative effect on interest rates. This may be explained by the fact that the recovery rates in Germany are relatively high, which holds especially true for collateralized loans like real estate loans (Franks et al. (2004)), so that German depositors tend to prefer banks originating loans that are highly collateralized. Similarly, the small p-values of the negative coefficients on the return on assets ratio and on the cash to assets ratio provide evidence against the null hypotheses that the interest expenditures do not respond to these variables. This suggests that depositors interpret good performance and liquidity as signals of sound health. Furthermore, the regression coefficient on risk expenditures to assets is positive. However, it is not statistically significant at a reasonable significance level. One tentative explanation for this is that German banks have various revaluation options and possibilities to build and release hidden reserves to conceal the

18 More detailed results are available upon request. 
"true" value of the risk expenditures. The general idea of hidden reserves is to allow banks to smooth the yearly fluctuations of their risk expenditures. Thus, an external reader of a bank's income statement may have problems to evaluate this variable or even may refrain from taking the figures into account in the first place.

The coefficients on material expenditures to assets and personnel expenditures to assets are strongly significant. Interestingly, high values of material and personnel expenditures to assets are associated with a negative impact on the interest rates. It seems as if the bank efficiency does not play as an important role as it does in similar studies of other countries. As described above, our prediction that depositors of German savings banks put more emphasis on an intensive local market coverage and on sponsorship than on banks' efficiency seems to be right. This allows savings banks to offer lower interest rates. Since we cannot prove causality, it could also be that banks with a strong standing in their market and thus lower interest rates on deposits need not care for cost reduction as much as others.

Assessing the goodness of fit: The F-test shows that bank risk characteristics are jointly significant and hence affect the level of interest rates. So does time. The $R^{2}$ within $^{19}(0.843)$ demonstrates that the estimated model can explain a lot of the variation within the units. The spread of the observations around the regression line (measured in units of the dependent variable) is relatively small, pointed out by the low S.E. of the regression (0.135). The estimate of rho (0.873) suggests that a high level of the variation in the dependent variable is related to the entity differences in the interest rates. Overall, the model appears to be well specified.

Summing up, the bank risk characteristics have considerable explanatory power for the interest rates. Nearly all independent bank risk variables are highly significant and most of them have the expected effect on the interest expenditures. This evidence suggests that savings banks have to pay higher interest rates when they take more risk. We consider this to be a strong signal for market discipline. This result confirms the studies which provide evidence that even fully insured depositors exert market discipline (see Section 2.1).

19 Defined as the squared correlation between deviations of $y_{i t}$ values from unit means $\left(y_{i t}-\bar{y}_{i}\right)$ and deviations of predicted values from unit mean predicted values $\left(\hat{y}_{i t}-\hat{y}_{i}\right)$. See Hamilton (2006), p. 195 . 


\section{Growth Rate of Bank Deposits}

Column three of Table 4 presents the results for the regression of the banks' deposit growth rates on risk characteristics. Firstly, the estimated regression coefficient on capital to assets is positive and statistically significant. Banks with more equity are perceived to be less risky and therefore have the ability to attract more bank deposits. Secondly, the very high and significant coefficient for personnel expenditures to assets (32.038) is astonishing at first glance. Remember that the mean of this variable amounts to $1.26 \%$. The regression coefficient is the predicted change in bank deposit growth for a one-percentage-point-increase of personnel expenditures to assets (holding the other independent variables constant). This does not seem as unrealistic as at first sight. The positive sign indicates once again that the cost efficiency of savings banks is of secondary importance for depositors. Thirdly, banks with higher return on assets ratios are characterized by a significantly higher bank deposit growth, which may indicate that depositors positively evaluate good bank performance. Furthermore, there is no statistical evidence that the remaining four bank risk characteristics (ratios of risk expenditures to assets, real estate loans and public loans to assets, material expenditures to assets, and cash to assets) significantly influence the bank's deposit growth. The absolute t-values of their estimated coefficients are clearly too small for a rejection of the individual null hypotheses at acceptable significance levels. An explanation for this lag of significance may be that bank depositors are in a far better position than other depositors to get more detailed information about a bank. They do not have to concentrate on a few popular financial ratios from annual reports for evaluating, e.g., asset quality and liquidity.

Assessing the goodness of fit: The F-tests for bank risk characteristics and for time effects are jointly significant and hence affect the bank deposit growth. The $R^{2}$ within $(0.249)$ is considerably weaker than it is for the price regression (see above). This is not surprising. We have to use growth rates instead of absolute levels (see Section 3), which has the disadvantage that statistical significance is decreasing because the growth rate distribution shows more noise. This can be seen in different studies examining both the price and the quantity effects (e.g. Martinez Peria and Schmukler (2001) or Ioannidou and de Dreu (2006)). The negative empirical correlation $(-0.660)$ between the estimated fixed entity effects and the fitted values of the 
dependent variable needs further research. ${ }^{20}$ Overall, although the model specification is very similar to those of other studies, the explanatory power is moderate.

In all, the results indicate that some bank risk characteristics can significantly explain the behavior of bank deposit growth and are therefore indicating evidence of market discipline by other banks. German savings banks with higher capital to assets, personnel expenditures to assets and return on assets ratios are characterized by a higher bank deposit growth rate.

\section{Growth Rate of Customer Deposits}

For customer deposits, the most important category with more than $60 \%$ of all liabilities (cf. Figure 5), we also find some evidence of market discipline. Banks with higher ratios of capital to assets, real estate loans and public loans to assets, and return on assets are characterized by a higher customer deposit growth. An increase in the risk expenditure to total assets ratio is associated with an expected withdrawal of customer deposits. It seems as if customers prefer conservative savings banks which use their sound capital base primarily for (local) low default investment like real estate loans and public loans. These results are quite surprising. They contradict the view that private depositors do not exert market discipline because they can be regarded sas small and unsophisticated. In addition we would think that they would not need to discipline the savings banks because as customers they are even more protected than banks as depositors (although in the case of savings banks the latter are also fully protected; cf. Section 2.2). In the theoretical literature we find arguments that small depositors are considered to be savers with limited financial literacy. In comparison to large depositors they have a disadvantage in discerning the riskiness of banks (Furlong (1984)). Our observations indicate that regarding all small depositors as unsophisticated may be far too easy. Possibly, as a group, although with no obvious coordination, they are able to put pressure on banks. This is an interesting, yet still open question. Finally, there is no apparent relation between efficiency, measured by personell and material expenditures to assets and the ability to attract more customer deposits.

20 In order to ensure comparability, we chose the same independent variables for each group of deposits. 
Assessing the goodness of fit: The F-tests show that bank risk characteristics and time effects are jointly significant. Customer deposits is interestingly the deposit category with, among the growth variables, the largest number of significant variables and with the highest $R^{2}$ within (0.337). The S.E. of the regression (2.629) as well as the negative empirical correlation between the estimated fixed entity effects and the fitted values of the dependent variable $(-0.244)$ are on a satisfactory level. Overall, the model appears to be accurately specified.

Summarizing, the customer deposit growth rate responds significantly to several bank risk characteristics providing evidence that, in contrast to the theoretical perspective, also small and unsophisticated depositors with completely protected deposits punish banks for being more risky.

\section{Growth Rate of Securitized Liabilities}

Column five of Table 4 shows the regression coefficients for the growth rate of securitized liabilities w.r.t. bank characteristics. We observe that only return on assets has a weakly significant positive effect on liability growth. For all other independent variables there is no significant link to the growth rate.

Assessing the goodness of fit: The hypothesis that the estimates of the bank risk characteristics are jointly equal to zero cannot be rejected. Therefore, we cannot infer that the included bank risk characteristics can significantly explain the growth rate of securitized liabilities. The very low $R^{2}$ within (0.084) and the high S.E. of the regression (21.268) also indicate a weak fit. Overall, the model cannot explain the variation in growth rates of securitized liabilities.

Therefore, there is no evidence that savings banks are disciplined by securitized liabilities. This may be explained by the composition of securitized liabilities, because different types of obligations belong to this balance sheet item and possibly discipline is exerted in various ways. Another possible explanation is that German savings banks issue these liabilities just occasionally and with no obvious pattern. The main holders are local authorities and other German savings banks which are possibly not as risk averse as or better informed than other depositors. As described in Section 2.2 they also have a higher incentive to back up. 


\section{Growth Rate of Subordinated Debt}

For this category of liabilities we do not see any significant relationship between bank fundamentals and the growth rate. Similarly to securitized liabilities, we find no evidence of market discipline. Again, a very low $R^{2}$ within (0.069) and a high S.E. of the regression (19.837) signal that the present model is badly specified.

Finding no evidence of market discipline via subordinated debt is in a way surprising. As mentioned above, some studies claim that uninsured large-scale depositors should react even more risk sensitive than other investors. However, subordinated debt of German savings banks is mainly held by local authorities ${ }^{21}$ and other savings banks which may have a vivid interest to foster the banks since the first technically own the institutes and the latter belong to the same deposit insurance system and, at the same time, do not compete with them. Further evidence with more detailed data concerning the debt features is needed to tackle this issue. Since subordinated debt is only issued fairly rarely - more than 800 (out of 2,770 ) observations show a growth rate of zero - we may also have to consider methodological adjustments.

\section{Brief Summary}

In broad terms, the regression results across the five different dependent variables w. r.t. individual bank risk characteristics confirm the presence of market discipline for German savings banks. Our findings for the reaction of the interest rates strongly support the presence of market discipline, whereas the results for the deposit growth are clearly weaker. Somewhat surprisingly, discipline via subordinated debt does not seem to exist. Interestingly, very high significance levels are observed - beside for the capital to assets ratio - for the return on assets ratio, although the German Commercial Code offers banks various possibilities to disguise the true value of their returns. Moreover, the efficiency indicators show a sign contrary to the one of our predecessor studies. We suppose that this can be explained by the intensive local market coverage of German savings banks. Based on the high customer loyalty they are not punished for higher personnel and material expenditures to assets ratios.

21 Savings banks often represent the primary banking relationship for public-sector clients. 


\section{Table 4: Overview of the Panel Regressions}

The table reports the fixed effects (within) regression results of the dependent variables w.r.t. bank risk characteristics. The full data set is used. Estimators for the fixed effects and the time dummies are not reported in order to save space. t-statistics are in parentheses. Clustered standard errors are computed. F-tests for time effects and bank risk characteristics test the null hypothesis that these variables are jointly equal to zero.

\begin{tabular}{|c|c|c|c|c|c|}
\hline \multirow[b]{2}{*}{ Explanatory Variables } & \multirow[b]{2}{*}{$\begin{array}{c}\text { Interest } \\
\text { Rates }\end{array}$} & \multicolumn{4}{|c|}{ Growth rates of } \\
\hline & & $\begin{array}{c}\text { Bank } \\
\text { deposits }\end{array}$ & $\begin{array}{c}\text { Customer } \\
\text { deposits }\end{array}$ & $\begin{array}{c}\text { Securitized } \\
\text { debt }\end{array}$ & $\begin{array}{c}\text { Subordinated } \\
\text { debt }\end{array}$ \\
\hline Lag(capital/assets $\cdot 100)$ & $\begin{array}{c}-0.046^{* *} \\
(-2.310)\end{array}$ & $\begin{array}{c}9.141^{* * *} \\
(6.124)\end{array}$ & $\begin{array}{c}0.962^{* * *} \\
(3.333)\end{array}$ & $\begin{array}{c}4.361 \\
(1.602)\end{array}$ & $\begin{array}{c}1.436 \\
(0.610)\end{array}$ \\
\hline Lag(risk expenditures/assets $\cdot 100)$ & $\begin{array}{c}0.019 \\
(1.553)\end{array}$ & $\begin{array}{c}0.488 \\
(0.407)\end{array}$ & $\begin{array}{l}-0.388^{*} \\
(-1.826)\end{array}$ & $\begin{array}{c}-2.570 \\
(-1.194)\end{array}$ & $\begin{array}{c}-2.302 \\
(-1.319)\end{array}$ \\
\hline Lag(real estate and public loans/assets · 100) & $\begin{array}{c}-0.006^{* * *} \\
(-2.917)\end{array}$ & $\begin{array}{c}0.123 \\
(0.718)\end{array}$ & $\begin{array}{l}0.053^{*} \\
(1.864)\end{array}$ & $\begin{array}{c}-0.021 \\
(-0.075)\end{array}$ & $\begin{array}{c}-0.264 \\
(-1.055)\end{array}$ \\
\hline Lag(personnel expenditures/assets $\cdot 100)$ & $\begin{array}{c}-0.297 * * * \\
(-5.008)\end{array}$ & $\begin{array}{c}32.038^{* * *} \\
(6.244)\end{array}$ & $\begin{array}{c}0.499 \\
(0.577)\end{array}$ & $\begin{array}{l}10.332 \\
(1.247)\end{array}$ & $\begin{array}{c}2.916 \\
(0.378)\end{array}$ \\
\hline Lag(material expenditures/assets $\cdot 100)$ & $\begin{array}{c}-0.136^{* * *} \\
(-3.556)\end{array}$ & $\begin{array}{c}1.871 \\
(0.491)\end{array}$ & $\begin{array}{c}0.318 \\
(0.439)\end{array}$ & $\begin{array}{c}4.054 \\
(0.556)\end{array}$ & $\begin{array}{c}3.897 \\
(0.701)\end{array}$ \\
\hline Lag(return/assets · 100) & $\begin{array}{c}-0.059 * * \\
(-2.475)\end{array}$ & $\begin{array}{c}3.990^{* *} \\
(2.080)\end{array}$ & $\begin{array}{c}0.998^{* * *} \\
(2.664)\end{array}$ & $\begin{array}{l}7.342^{*} \\
(1.727)\end{array}$ & $\begin{array}{c}3.351 \\
(1.329)\end{array}$ \\
\hline $\operatorname{Lag}(\operatorname{cash} /$ assets $\cdot 100)$ & $\begin{array}{c}-0.016^{* * *} \\
(-3.331)\end{array}$ & $\begin{array}{c}-0.121 \\
(-0.151)\end{array}$ & $\begin{array}{c}0.015 \\
(0.129)\end{array}$ & $\begin{array}{c}0.519 \\
(0.588)\end{array}$ & $\begin{array}{c}-0.463 \\
(-0.590)\end{array}$ \\
\hline Constant & $\begin{array}{l}4.218^{* * *} \\
(40.854)\end{array}$ & $\begin{array}{c}-67.514^{* * * *} \\
(-7.559)\end{array}$ & $\begin{array}{c}-5.507^{* * *} \\
(-3.649)\end{array}$ & $\begin{array}{c}-41.323^{* * *} \\
(-3.086)\end{array}$ & $\begin{array}{c}-0.167 \\
(-0.015)\end{array}$ \\
\hline Observations & 3296 & 3296 & 3296 & 2830 & 2743 \\
\hline Number of groups & 631 & 631 & 631 & 577 & 552 \\
\hline S.E. of regression & 0.135 & 12.997 & 2.629 & 21.268 & 19.837 \\
\hline R-Squared within & 0.843 & 0.249 & 0.337 & 0.084 & 0.069 \\
\hline $\operatorname{corr}(\mathrm{u} \quad \mathrm{i}, \mathrm{Xb})$ & -0.086 & -0.660 & -0.244 & -0.205 & -0.146 \\
\hline rho & 0.873 & 0.483 & 0.337 & 0.475 & 0.409 \\
\hline F-test risk characteristics & $13.743^{* * *}$ & $17.090^{* * *}$ & $4.161^{* * *}$ & 1.673 & 0.695 \\
\hline F-test time effects & $756.836^{* * *}$ & $60.607^{* * *}$ & $189.223^{* * *}$ & $20.608^{* * *}$ & $15.226^{* * *}$ \\
\hline
\end{tabular}

$t$ statistics in parentheses

$* p<0.10, * * p<0.05, * * * p<0.01$ 


\subsection{Regressions of sub-groups}

In Tables 14 through 18 of Appendix A.4, the regressions for the five dependent variables of Table 4 are each split up into three pairs: balanced vs. unbalanced panel, West Germany vs. East Germany, larger banks vs. smaller banks. ${ }^{22}$ Overall, the results in the Appendix support the findings presented above, especially for the balanced panel. Therefore, they show some robustness of our findings and are not discussed in detail for the moment. Nevertheless, we want to point out two interesting results regarding the relation between interest rates and banks' risk.

Too big to fail? Table 14 on page 38 displays in column 7 that all independent variables are statistically significant for small institutions. In contrast, for large banks we observe that only the ratios of real estate loans and public loans to assets and of personnel expenditures to assets have a significant effect on interest rates. This evidence suggests that deposits of larger banks are perceived to be safer and therefore depositors have weaker incentives to exert market discipline. Apparently this is not in line with the fact that all deposits are covered by the same institutional assistance scheme.

East Germany: Table 14 on page 38 shows significant point estimates for both of the asset quality variables in column 5 . This is surprising for risk expenditures to total assets, because this variable is seldomly statistically significant at a reasonable significance level. The variable real estate and public loans to total assets has a sign contrary to the one expected. Although these loans are highly collateralized, insured depositors request higher risk premia for higher values of this variable. A tentative explanation for this results is that due to the 1990s crisis of the mortgage industry in the eastern part of Germany, depositors may not perceive banks with a focus on real estate loans as less but rather as more risky. In this respect savings banks in the eastern part of Germany seem to be disciplined differently from their western counterparts, although, again, deposits are equally safe in both parts of the country.

22 Cf. Tables 6 through 10 (Appendix A.1) for the summary statistics of the sub-groups. 


\section{Conclusions}

Using bank-level accounting data from 1998 through 2005 for German savings banks, we investigate market discipline by depositors who all can be regarded as fully insured. We test its presence by examining the impact of bank risk characteristics on interest rates and on growth rates of deposits.

Notwithstanding full insurance of all deposits via an institutional assistance scheme, our results provide evidence of market discipline at German savings banks. Even fully insured depositors discipline riskier banks significantly by requesting higher risk premia. Our findings for the withdrawal behavior also indicate some market discipline, but the results are clearly weaker. The empirical results may indicate that the deposit insurance is not sufficiently known about or is not always perceived as fully credible. Depositors may want to avoid a loss arising in case of a bank failure, such as an incomplete payout or the waiting costs for deposit redemption. Finally, our results are in accordance with the few empirical studies which find that insured depositors, too, respond to the financial conditions of banks and are concerned about the solvency of banks.

For the German banking market further empirical research is needed. Besides the derived questions, possibly the most natural extension of our design is to conduct our study for the other pillars of the system. The cooperative banks, for example, also cover deposits by a similar institutional assistance scheme but do not enjoy a state guarantee. Furthermore, a methodological extension of our paper would be to integrate maturities of deposit categories to take into account the term structure and hopefully obtain more specific results. Our future research will take an anticipated too big to fail guarantee and the influence of different macroeconomic circumstances of German savings banks into account in more detail, too. 


\section{A Appendix}

\section{A.1 Descriptive Statistics}
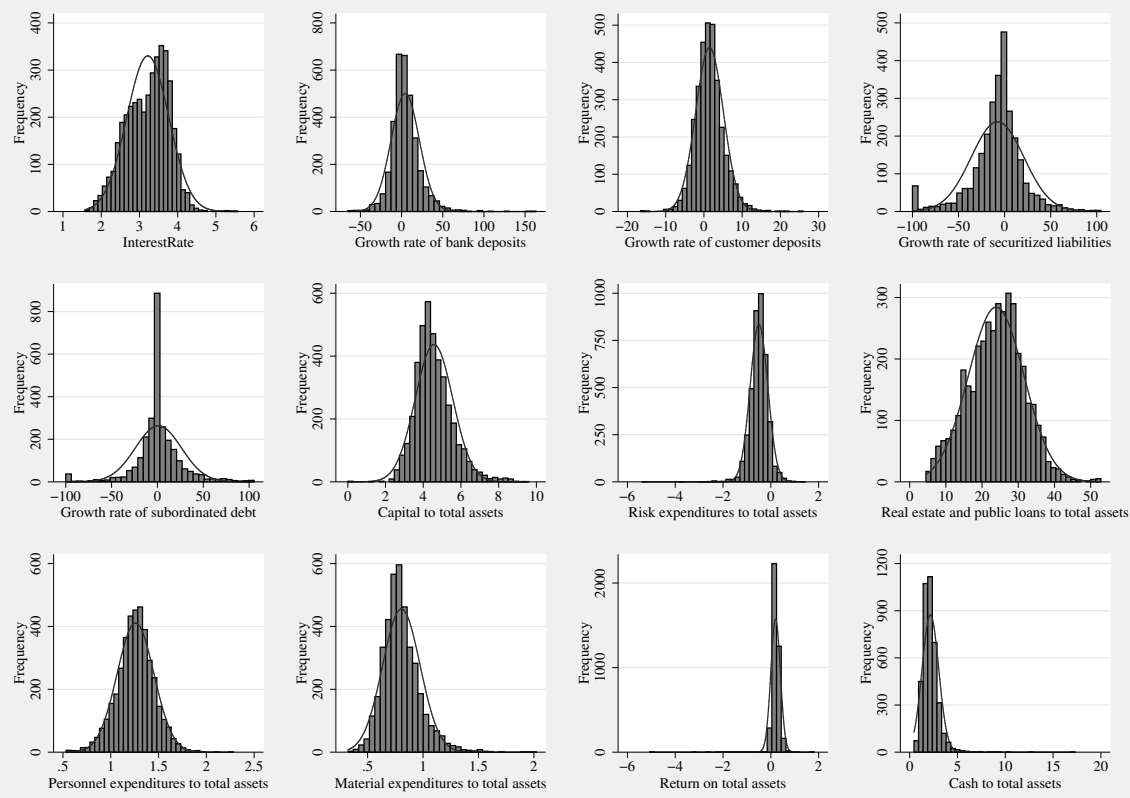

Figure 6: Histograms of the dependent and independent variables for all savings banks*

* Note that we do not use values above the 99 percentile in the histograms and the panel regressions for securitized liabilities and subordinated debt.

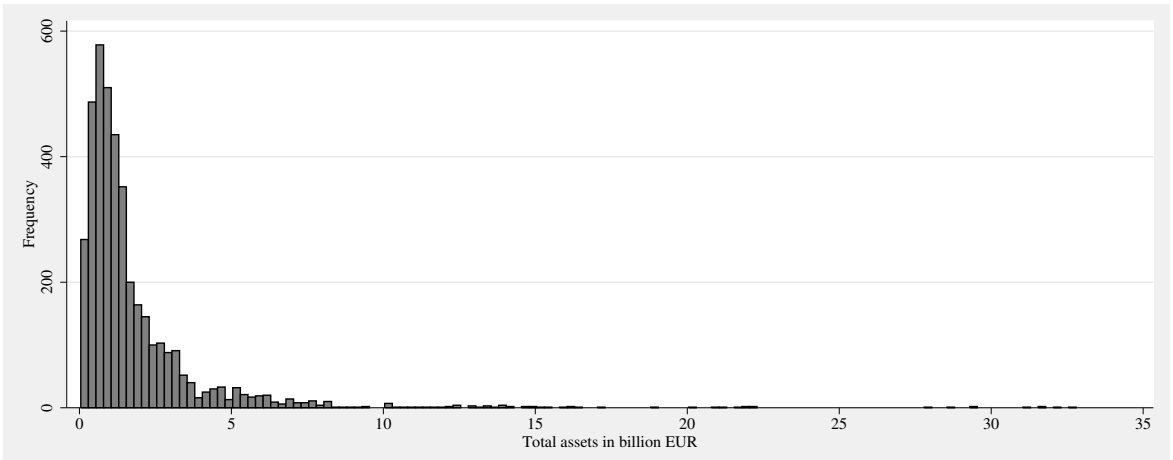

Figure 7: Histogram of total assets for all savings banks 


\begin{tabular}{cccccc}
\hline \multirow{2}{*}{$\begin{array}{c}\text { Observ. } \\
\text { by entity }\end{array}$} & \multicolumn{2}{c}{ Total observations } & & \multicolumn{2}{c}{ Total entities } \\
\cline { 2 - 3 } \cline { 5 - 6 } \cline { 5 - 6 } & Freq. & Percent & & Freq. & Percent \\
\hline 1 & 51 & 1.28 & & 51 & 7.48 \\
3 & 86 & 2.16 & & 43 & 6.30 \\
4 & 210 & 5.28 & & 70 & 10.26 \\
5 & 240 & 6.03 & & 60 & 8.80 \\
6 & 275 & 6.91 & & 55 & 8.06 \\
7 & 210 & 5.28 & & 35 & 5.13 \\
8 & 266 & 6.69 & & 38 & 5.57 \\
\hline Total & 2,640 & 66.37 & & 330 & 48.39 \\
\hline
\end{tabular}

Table 5: Number of observations by entity in the final data set

\begin{tabular}{rrrrrrrrr}
\hline Variable & $\mathbf{N}$ & Mean & Std. Dev. & Min & P1 & P50 & P99 & Max \\
\hline irate (\%) & 2,640 & 3.16 & 0.54 & 1.57 & 1.92 & 3.21 & 4.23 & 5.24 \\
bank (\%) & 2,310 & 4.11 & 16.92 & -65.20 & -37.09 & 2.35 & 54.15 & 163.72 \\
custom (\%) & 2,310 & 1.48 & 3.55 & -14.20 & -6.29 & 1.32 & 11.05 & 25.90 \\
secur (\%) & 1,963 & -2.35 & 123.43 & -100.00 & -100.00 & -4.53 & 128.07 & 5000.00 \\
subord (\%) & 1,890 & 1.76 & 30.14 & -100.00 & -100.00 & 0.00 & 98.11 & 473.42 \\
equity (\%) & 2,640 & 4.58 & 0.98 & 2.31 & 2.83 & 4.44 & 7.89 & 9.59 \\
risk (\%) & 2,640 & -0.50 & 0.36 & -5.39 & -1.39 & -0.50 & 0.37 & 1.44 \\
real (\%) & 2,640 & 23.67 & 7.89 & 4.48 & 7.17 & 23.73 & 42.35 & 52.82 \\
person (\%) & 2,640 & 1.25 & 0.20 & 0.53 & 0.73 & 1.26 & 1.73 & 1.98 \\
mater (\%) & 2,640 & 0.80 & 0.17 & 0.32 & 0.46 & 0.78 & 1.28 & 1.60 \\
return (\%) & 2,640 & 0.20 & 0.17 & -5.07 & 0.00 & 0.20 & 0.54 & 1.81 \\
cash (\%) & 2,640 & 2.20 & 0.86 & 0.53 & 0.86 & 2.09 & 5.02 & 10.55 \\
assets (bn EUR) & 2,640 & 1.59 & 1.79 & 0.15 & 0.21 & 1.11 & 10.29 & 16.38 \\
\hline
\end{tabular}

Table 6: Summary statistics of the balanced data set

\begin{tabular}{rrrrrrrrr}
\hline Variable & $\mathbf{N}$ & Mean & Std. Dev. & Min & P1 & P50 & P99 & Max \\
\hline irate (\%) & 3,319 & 3.35 & 0.47 & 1.85 & 2.29 & 3.42 & 4.31 & 5.57 \\
bank (\%) & 2,739 & 5.37 & 16.62 & -65.20 & -32.68 & 3.59 & 56.56 & 163.72 \\
custom (\%) & 2,739 & 1.55 & 3.69 & -16.02 & -6.65 & 1.43 & 11.91 & 25.90 \\
secur (\%) & 2,494 & -3.02 & 115.46 & -100.00 & -100.00 & -5.30 & 111.76 & 5000.00 \\
subord (\%) & 2,238 & 2.62 & 32.11 & -100.00 & -100.00 & 0.00 & 103.43 & 473.42 \\
equity (\%) & 3,319 & 4.74 & 0.95 & 0.16 & 3.10 & 4.58 & 7.97 & 9.59 \\
risk (\%) & 3,319 & -0.47 & 0.36 & -5.39 & -1.41 & -0.46 & 0.43 & 1.44 \\
real (\%) & 3,319 & 25.83 & 6.62 & 5.73 & 10.69 & 25.91 & 42.23 & 52.82 \\
person (\%) & 3,319 & 1.28 & 0.20 & 0.53 & 0.74 & 1.28 & 1.74 & 2.28 \\
mater (\%) & 3,319 & 0.76 & 0.13 & 0.32 & 0.46 & 0.76 & 1.14 & 1.70 \\
return (\%) & 3,319 & 0.21 & 0.20 & -5.07 & 0.00 & 0.21 & 0.55 & 1.70 \\
cash (\%) & 3,319 & 2.05 & 0.82 & 0.45 & 0.79 & 1.94 & 4.78 & 17.28 \\
assets (bn EUR) & 3,319 & 1.91 & 2.70 & 0.04 & 0.17 & 1.19 & 13.80 & 32.70 \\
\hline
\end{tabular}

Table 7: Summary statistics of the West German data set 


\begin{tabular}{rrrrrrrrr}
\hline Variable & N & Mean & Std. Dev. & Min & P1 & P50 & P99 & Max \\
\hline irate (\%) & 659 & 2.54 & 0.38 & 1.57 & 1.75 & 2.55 & 3.38 & 3.80 \\
bank (\%) & 557 & -0.12 & 19.00 & -59.16 & -48.08 & -2.23 & 57.64 & 106.42 \\
custom (\%) & 557 & 1.13 & 3.31 & -16.58 & -5.88 & 0.87 & 10.40 & 13.05 \\
secur (\%) & 378 & 7.62 & 67.53 & -100.00 & -100.00 & 2.05 & 310.08 & 771.43 \\
subord (\%) & 532 & 3.88 & 31.92 & -100.00 & -87.93 & 0.00 & 116.82 & 343.48 \\
equity (\%) & 659 & 3.72 & 0.75 & 0.00 & 2.42 & 3.64 & 5.81 & 7.04 \\
risk (\%) & 659 & -0.65 & 0.37 & -2.54 & -1.73 & -0.64 & 0.27 & 0.52 \\
real (\%) & 659 & 14.17 & 4.92 & 4.48 & 5.14 & 14.31 & 25.17 & 26.48 \\
person (\%) & 659 & 1.18 & 0.14 & 0.70 & 0.83 & 1.18 & 1.52 & 1.65 \\
mater (\%) & 659 & 1.01 & 0.18 & 0.60 & 0.66 & 0.98 & 1.58 & 2.02 \\
return (\%) & 659 & 0.16 & 0.21 & -2.22 & -0.70 & 0.15 & 0.63 & 1.81 \\
cash (\%) & 659 & 2.75 & 0.89 & 0.98 & 1.23 & 2.64 & 5.65 & 10.55 \\
assets (bn EUR) & 659 & 1.31 & 1.14 & 0.20 & 0.41 & 0.96 & 6.67 & 9.17 \\
\hline
\end{tabular}

Table 8: Summary statistics of the East German data set

\begin{tabular}{rrrrrrrrr}
\hline Variable & N & Mean & Std. Dev. & Min & P1 & P50 & P99 & Max \\
\hline irate (\%) & 1,391 & 3.24 & 0.53 & 1.75 & 2.01 & 3.31 & 4.25 & 5.57 \\
bank (\%) & 1,147 & 4.77 & 16.53 & -47.83 & -32.78 & 2.95 & 58.35 & 163.72 \\
custom (\%) & 1,147 & 1.52 & 3.48 & -14.20 & -5.90 & 1.30 & 11.02 & 21.77 \\
secur (\%) & 1,120 & -1.61 & 52.18 & -100.00 & -97.92 & -4.98 & 126.73 & 1150.00 \\
subord (\%) & 1,004 & 2.54 & 31.57 & -100.00 & -86.79 & 0.00 & 109.92 & 473.42 \\
equity (\%) & 1,391 & 4.55 & 0.92 & 1.81 & 2.63 & 4.45 & 7.27 & 9.59 \\
risk (\%) & 1,391 & -0.49 & 0.33 & -2.80 & -1.32 & -0.49 & 0.35 & 0.99 \\
real (\%) & 1,391 & 23.10 & 7.42 & 4.48 & 5.89 & 24.29 & 38.64 & 46.55 \\
person (\%) & 1,391 & 1.19 & 0.20 & 0.53 & 0.69 & 1.20 & 1.63 & 1.91 \\
mater (\%) & 1,391 & 0.76 & 0.15 & 0.32 & 0.46 & 0.75 & 1.24 & 1.52 \\
return (\%) & 1,391 & 0.19 & 0.14 & -1.94 & 0.00 & 0.19 & 0.51 & 1.17 \\
cash (\%) & 1,391 & 2.06 & 0.92 & 0.53 & 0.74 & 1.92 & 5.83 & 10.55 \\
assets (bn EUR) & 1,391 & 3.71 & 3.52 & 1.50 & 1.51 & 2.67 & 21.68 & 32.70 \\
\hline
\end{tabular}

Table 9: Summary statistics of the data set of large institutions (assets $>1.5$ bn EUR)

\begin{tabular}{rrrrrrrrr}
\hline Variable & N & Mean & Std. Dev. & Min & P1 & P50 & P99 & Max \\
\hline irate (\%) & 2,587 & 3.21 & 0.56 & 1.57 & 1.92 & 3.29 & 4.29 & 5.24 \\
bank (\%) & 2,149 & 4.27 & 17.50 & -65.20 & -38.21 & 2.45 & 54.65 & 155.76 \\
custom (\%) & 2,149 & 1.46 & 3.71 & -16.58 & -6.78 & 1.33 & 11.91 & 25.90 \\
secur (\%) & 1,752 & -1.63 & 135.07 & -100.00 & -100.00 & -3.94 & 135.85 & 5000.00 \\
subord (\%) & 1,766 & 3.05 & 32.36 & -100.00 & -100.00 & 0.00 & 104.05 & 414.29 \\
equity (\%) & 2,587 & 4.58 & 1.04 & 0.00 & 2.75 & 4.42 & 8.07 & 9.25 \\
risk (\%) & 2,587 & -0.50 & 0.39 & -5.39 & -1.61 & -0.48 & 0.44 & 1.44 \\
real (\%) & 2,587 & 24.32 & 7.82 & 4.98 & 7.61 & 24.35 & 42.26 & 52.82 \\
person (\%) & 2,587 & 1.30 & 0.18 & 0.61 & 0.87 & 1.29 & 1.76 & 2.28 \\
mater (\%) & 2,587 & 0.83 & 0.18 & 0.34 & 0.50 & 0.80 & 1.37 & 2.02 \\
return (\%) & 2,587 & 0.20 & 0.22 & -5.07 & 0.00 & 0.20 & 0.59 & 1.81 \\
cash (\%) & 2,587 & 2.23 & 0.84 & 0.45 & 0.89 & 2.12 & 4.79 & 17.28 \\
assets (bn EUR) & 2,587 & 0.80 & 0.37 & 0.04 & 0.16 & 0.77 & 1.48 & 1.50 \\
\hline
\end{tabular}

Table 10: Summary statistics of the data set of small institutions (assets $\leq 1.5$ bn EUR) 


\section{A.2 Structure of Annual Reports based on the German Com- mercial Code}

\begin{tabular}{|c|c|c|c|}
\hline \multicolumn{2}{|l|}{ Assets } & \multicolumn{2}{|c|}{ Liabilities and equity } \\
\hline A1. & Cash reserve & L1. & Bank deposits \\
\hline $\mathrm{A} 2$. & $\begin{array}{l}\text { Debt instruments issued by public } \\
\text { authorities and bills approved for } \\
\text { refinancing through Deutsche } \\
\text { Bundesbank }\end{array}$ & L2. & Customer deposits \\
\hline A3. & Due from banks & L3. & Securitized liabilities \\
\hline A4. & $\begin{array}{l}\text { Due from customers } \\
\text { thereof: } \\
\text { Secured by mortgages } \\
\text { Public sector loans }\end{array}$ & L4. & Trust liabilities \\
\hline A5. & $\begin{array}{l}\text { Debentures and other fixed-interest } \\
\text { securities }\end{array}$ & L5. & Other liabilities \\
\hline A6. & $\begin{array}{l}\text { Shares and other non-fixed interest } \\
\text { securities }\end{array}$ & L6. & Deferred income \\
\hline A7. & Participating interests & L7. & Provisions \\
\hline A8. & Shares in affiliated companies & L8. & Special reserve item \\
\hline A9. & Trust assets & L9. & Subordinated debt \\
\hline A10. & $\begin{array}{l}\text { Equalization amounts from public } \\
\text { authorities }\end{array}$ & L10. & Participatory capital \\
\hline A11. & Intangible assets & L11. & Funds for general bank risks \\
\hline A12. & Tangible assets & L12. & Equity \\
\hline A13. & Other assets & & \\
\hline \multicolumn{2}{|c|}{ Total assets } & \multicolumn{2}{|c|}{ Total liabilities and equity } \\
\hline
\end{tabular}

Table 11: Balance Sheet (compressed) 


\section{Income statement}

I1. Interest income

I2. Interest expenses

I3. Current income from shares and other variable-yield securities, participating interests and shares in affiliated companies

I4. Income from participating interests in joint venture enterprises and associated companies

I5. Income from profit pooling, profit transfer agreements and partial profit transfer agreements

I6. Commission income

I7. Commission expenses

I8. Net income or net expenditure from financial and investment banking

I9. Other operating income

I10. General administrative expenses

a) Personnel expenses

b) Other administrative expenses

I11. Depreciation and value adjustments on amounts due to certain securities and allocations to provisions for loan business

I12. Other operating expenses

I13. Depreciation and value adjustments on amounts due and certain securities and allocations to provisions for loan business

I14. Income from additions to amounts due and certain securities and the release of provisions for possible loan losses

I15. Depreciation and value adjustments on trade investments, shares in affiliated companies and securities treated as fixed assets.

I17. Expenditures resulting from the accepting of losses

I18. Allocations to special reserve items

I19. Profit (loss) of ordinary activities

I20. Extraordinary income

I21. Extraordinary expenses

I22. Extraordinary profit (loss)

I23. Taxes on income and earnings

I24. Other taxes not reported under item 12

I25. Income from loss assumption

I26. Profits deducted in relation to profit-pooling, profit transfer agreements and partial profit transfer agreements

I27. Net income for the year

Table 12: Income Statement (compressed) 


\section{A.3 Definition of Variables}

\begin{tabular}{|c|c|c|}
\hline Variable & Short name & Calculation \\
\hline \multicolumn{3}{|l|}{ Dependent Variables } \\
\hline Implicit interest rate & irate & $\left(\frac{I 2}{L 1+L 2+L 3+L 9+L 10}\right) \cdot 100$ \\
\hline Growth rate of bank deposits & bank & $\left(\frac{L 1_{t}-L 1_{t-1}}{L 1_{t-1}}\right) \cdot 100$ \\
\hline Growth rate of customer deposits & custom & $\left(\frac{L 2_{t}-L 2_{t-1}}{L 2_{t-1}}\right) \cdot 100$ \\
\hline Growth rate of securitized liabilities & secur & $\left(\frac{L 3_{t}-L 3_{t-1}}{L 3_{t-1}}\right) \cdot 100$ \\
\hline Growth rate of subordinated debt & subord & $\left(\frac{L 9_{t}-L 9_{t-1}}{L 9_{t-1}}\right) \cdot 100$ \\
\hline \multicolumn{3}{|l|}{ Independent Variables } \\
\hline Capital to assets & equity & $\left(\frac{L 11+L 12}{\text { Total assets }}\right) \cdot 100$ \\
\hline Risk expenditures to assets & risk & $\left(\frac{I 13+I 14}{\text { Total assets }}\right) \cdot 100$ \\
\hline Real estate and public loans to assets & real & $\left(\frac{A 4 " \text { thereof" }}{\text { Total assets }}\right) \cdot 100$ \\
\hline Personnel expenditures to assets & person & $\left(\frac{I 10 a}{\text { Total assets }}\right) \cdot 100$ \\
\hline Material expenditures to assets & mater & $\left(\frac{I 10 b+I 11}{\text { Total assets }}\right) \cdot 100$ \\
\hline Return on assets & return & $\left(\frac{I 27}{\text { Total assets }}\right) \cdot 100$ \\
\hline Cash to assets & cash & $\left(\frac{A 1}{\text { Total assets }}\right) \cdot 100$ \\
\hline \multicolumn{3}{|l|}{ In addition } \\
\hline Total assets & assets & $\sum_{i=1}^{13}\left(A_{i}\right)=\sum_{j=1}^{12}\left(L_{j}\right)$ \\
\hline
\end{tabular}

Table 13: Definition of Variables 


\section{A.4 Detailed Panel Regression Results}

The following five pages contain of the tables of the detailed panel regression results. They are described in Section 5.2 on page 29. 
Table 14: Interest Rates

The table reports the fixed effects (within) regression results of the interest rates paid on interest bearing liabilities w.r.t. bank risk characteristics. Estimators for the fixed effects and the time dummies are not reported in order to save space. t-statistics are in parentheses. Clustered standard errors are computed. F-tests for time effects and bank risk characteristics test the null hypothesis that these variables are jointly equal to zero.

\begin{tabular}{|c|c|c|c|c|c|c|}
\hline \multirow[b]{2}{*}{ Explanatory Variables } & \multicolumn{2}{|c|}{ Panel Structure } & \multicolumn{2}{|c|}{ West-/East Germany } & \multicolumn{2}{|c|}{ Bank Size } \\
\hline & Unbalanced & Balanced & West & East & Large & Small \\
\hline Lag(capital/assets · 100) & $\begin{array}{c}-0.046^{* *} \\
(-2.310)\end{array}$ & $\begin{array}{c}-0.037^{*} \\
(-1.699)\end{array}$ & $\begin{array}{c}-0.056^{* *} \\
(-2.523)\end{array}$ & $\begin{array}{c}0.005 \\
(0.171)\end{array}$ & $\begin{array}{c}-0.015 \\
(-0.330)\end{array}$ & $\begin{array}{c}-0.062^{* * *} \\
(-2.865)\end{array}$ \\
\hline Lag(risk expenditures/assets $\cdot 100)$ & $\begin{array}{c}0.019 \\
(1.553)\end{array}$ & $\begin{array}{l}0.008 \\
(0.510)\end{array}$ & $\begin{array}{c}0.010 \\
(0.674)\end{array}$ & $\begin{array}{c}0.035^{* *} \\
(2.016)\end{array}$ & $\begin{array}{c}0.032 \\
(1.528)\end{array}$ & $\begin{array}{l}0.026^{*} \\
(1.796)\end{array}$ \\
\hline Lag(real estate and public loans/assets $\cdot 100)$ & $\begin{array}{c}-0.006 * * * \\
(-2.917)\end{array}$ & $\begin{array}{l}-0.004^{*} \\
(-1.751)\end{array}$ & $\begin{array}{c}-0.007^{* * *} \\
(-3.524)\end{array}$ & $\begin{array}{c}0.008^{* *} \\
(2.008)\end{array}$ & $\begin{array}{l}-0.006^{*} \\
(-1.837)\end{array}$ & $\begin{array}{c}-0.005^{* *} \\
(-2.147)\end{array}$ \\
\hline Lag(personnel expenditures/assets $\cdot 100)$ & $\begin{array}{c}-0.297^{* * *} \\
(-5.008)\end{array}$ & $\begin{array}{c}-0.317^{* * *} \\
(-4.441)\end{array}$ & $\begin{array}{c}-0.365 * * * \\
(-5.920)\end{array}$ & $\begin{array}{c}-0.091 \\
(-0.866)\end{array}$ & $\begin{array}{c}-0.392^{* * *} \\
(-3.677)\end{array}$ & $\begin{array}{c}-0.255^{* * *} \\
(-3.651)\end{array}$ \\
\hline Lag(material expenditures/assets $\cdot 100)$ & $\begin{array}{c}-0.136^{* * *} \\
(-3.556)\end{array}$ & $\begin{array}{c}-0.138^{* * *} \\
(-2.810)\end{array}$ & $\begin{array}{c}-0.030 \\
(-0.606)\end{array}$ & $\begin{array}{c}-0.195^{* *} \\
(-2.521)\end{array}$ & $\begin{array}{c}-0.017 \\
(-0.203)\end{array}$ & $\begin{array}{c}-0.172^{* * *} \\
(-4.038)\end{array}$ \\
\hline Lag(return/assets · 100) & $\begin{array}{c}-0.059^{* *} \\
(-2.475)\end{array}$ & $\begin{array}{l}-0.046^{*} \\
(-1.699)\end{array}$ & $\begin{array}{c}-0.039 \\
(-1.200)\end{array}$ & $\begin{array}{c}-0.096^{* *} \\
(-2.170)\end{array}$ & $\begin{array}{c}0.029 \\
(0.581)\end{array}$ & $\begin{array}{c}-0.080^{* * *} \\
(-3.548)\end{array}$ \\
\hline $\operatorname{Lag}($ cash/assets $\cdot 100)$ & $\begin{array}{c}-0.016^{* * *} \\
(-3.331)\end{array}$ & $\begin{array}{c}-0.015^{* * *} \\
(-2.676)\end{array}$ & $\begin{array}{c}-0.019 * * * \\
(-3.763)\end{array}$ & $\begin{array}{l}-0.014^{*} \\
(-1.985)\end{array}$ & $\begin{array}{c}-0.009 \\
(-1.202)\end{array}$ & $\begin{array}{c}-0.020^{* * *} \\
(-3.460)\end{array}$ \\
\hline Constant & $\begin{array}{l}4.218^{* * *} \\
(40.854) \\
\end{array}$ & $\begin{array}{c}4.139^{* * *} \\
(35.996) \\
\end{array}$ & $\begin{array}{c}4.478^{* * *} \\
(39.949) \\
\end{array}$ & $\begin{array}{c}2.806^{* * *} \\
(21.067) \\
\end{array}$ & $\begin{array}{c}4.147^{* * * *} \\
(22.484) \\
\end{array}$ & $\begin{array}{c}4.234^{* * *} \\
(33.922) \\
\end{array}$ \\
\hline Observations & 3296 & 2310 & 2739 & 557 & 1147 & 2149 \\
\hline Number of groups & 631 & 330 & 538 & 93 & 250 & 412 \\
\hline S.E. of regression & 0.135 & 0.142 & 0.137 & 0.105 & 0.135 & 0.132 \\
\hline R-Squared within & 0.843 & 0.856 & 0.849 & 0.869 & 0.854 & 0.840 \\
\hline $\operatorname{corr}\left(u_{\text {_ }} \mathrm{i}, \mathrm{Xb}\right)$ & -0.086 & -0.066 & -0.024 & 0.055 & -0.115 & -0.080 \\
\hline rho - & 0.873 & 0.861 & 0.719 & 0.739 & 0.830 & 0.891 \\
\hline F-test risk characteristics & $13.743^{* * *}$ & $9.341^{* * *}$ & $16.089^{* * *}$ & $2.816^{* *}$ & $4.467^{* * *}$ & $11.435^{* * *}$ \\
\hline F-test time effects & $756.836^{* * *}$ & $577.215^{* * *}$ & $562.036^{* * *}$ & $265.064^{* * *}$ & $247.771^{* * *}$ & $513.129^{* * *}$ \\
\hline
\end{tabular}

$t$ statistics in parentheses
${ }^{*} p<0.10,{ }^{* *} p<0.05,{ }^{* * *} p<0.01$ 
Table 15: Growth rate of bank deposits

The table reports the fixed effects (within) regression results of the bank deposit growth rate w.r.t. bank risk characteristics. Estimators for the fixed effects and the time dummies are not reported in order to save space. t-statistics are in parentheses. Clustered standard errors are computed. F-tests for time effects and bank risk characteristics test the null hypothesis that these variables are jointly equal to zero.

\begin{tabular}{|c|c|c|c|c|c|c|}
\hline \multirow[b]{2}{*}{ Explanatory Variables } & \multicolumn{2}{|c|}{ Panel Structure } & \multicolumn{2}{|c|}{ West-/East Germany } & \multicolumn{2}{|c|}{ Bank Size } \\
\hline & Unbalanced & Balanced & West & East & Large & Small \\
\hline Lag(capital/assets · 100) & $\begin{array}{c}9.141^{* * *} \\
(6.124)\end{array}$ & $\begin{array}{c}8.613^{* * *} \\
(5.113)\end{array}$ & $\begin{array}{c}8.630^{* * *} \\
(5.628)\end{array}$ & $\begin{array}{c}9.461^{* *} \\
(2.016)\end{array}$ & $\begin{array}{c}6.207^{* *} \\
(2.258)\end{array}$ & $\begin{array}{c}10.942^{* * * *} \\
(6.731)\end{array}$ \\
\hline Lag(risk expenditures/assets $\cdot 100)$ & $\begin{array}{c}0.488 \\
(0.407)\end{array}$ & $\begin{array}{c}0.675 \\
(0.495)\end{array}$ & $\begin{array}{c}0.992 \\
(0.837)\end{array}$ & $\begin{array}{c}-2.011 \\
(-0.608)\end{array}$ & $\begin{array}{c}-3.234 \\
(-1.528)\end{array}$ & $\begin{array}{l}2.563^{*} \\
(1.821)\end{array}$ \\
\hline Lag(real estate and public loans/assets $\cdot 100)$ & $\begin{array}{c}0.123 \\
(0.718)\end{array}$ & $\begin{array}{c}0.021 \\
(0.111)\end{array}$ & $\begin{array}{c}0.278 \\
(1.493)\end{array}$ & $\begin{array}{c}-0.473 \\
(-1.146)\end{array}$ & $\begin{array}{l}-0.311 \\
(-1.199)\end{array}$ & $\begin{array}{c}0.322 \\
(1.586)\end{array}$ \\
\hline Lag(personnel expenditures/assets $\cdot 100)$ & $\begin{array}{c}32.038^{* * *} \\
(6.244)\end{array}$ & $\begin{array}{c}32.963^{* * *} \\
(5.273)\end{array}$ & $\begin{array}{c}27.990^{* * *} \\
(5.226)\end{array}$ & $\begin{array}{c}50.627^{* * *} \\
(3.427)\end{array}$ & $\begin{array}{c}51.153^{* * *} \\
(5.319)\end{array}$ & $\begin{array}{c}27.064^{* * *} \\
(4.425)\end{array}$ \\
\hline Lag(material expenditures/assets $\cdot 100)$ & $\begin{array}{c}1.871 \\
(0.491)\end{array}$ & $\begin{array}{c}3.593 \\
(0.699)\end{array}$ & $\begin{array}{c}4.371 \\
(1.040)\end{array}$ & $\begin{array}{c}3.656 \\
(0.462)\end{array}$ & $\begin{array}{l}10.193 \\
(1.271)\end{array}$ & $\begin{array}{c}-0.041 \\
(-0.010)\end{array}$ \\
\hline Lag(return/assets · 100) & $\begin{array}{c}3.990^{* *} \\
(2.080)\end{array}$ & $\begin{array}{c}5.842^{* * *} \\
(2.746)\end{array}$ & $\begin{array}{l}4.227^{* *} \\
(2.112)\end{array}$ & $\begin{array}{c}6.085 \\
(1.054)\end{array}$ & $\begin{array}{c}-0.065 \\
(-0.012)\end{array}$ & $\begin{array}{c}2.819 \\
(1.549)\end{array}$ \\
\hline $\operatorname{Lag}(\operatorname{cash} /$ assets $\cdot 100)$ & $\begin{array}{c}-0.121 \\
(-0.151)\end{array}$ & $\begin{array}{c}0.730 \\
(1.375)\end{array}$ & $\begin{array}{c}-0.934 \\
(-1.034)\end{array}$ & $\begin{array}{c}3.050^{* *} \\
(2.543)\end{array}$ & $\begin{array}{c}0.510 \\
(0.868)\end{array}$ & $\begin{array}{c}-0.604 \\
(-0.494)\end{array}$ \\
\hline Constant & $\begin{array}{c}-67.514^{* * *} \\
(-7.559)\end{array}$ & $\begin{array}{c}-67.322^{* * *} \\
(-6.653)\end{array}$ & $\begin{array}{c}-65.524^{* * *} \\
(-6.986)\end{array}$ & $\begin{array}{c}-86.409^{* * *} \\
(-3.585)\end{array}$ & $\begin{array}{c}-69.433^{* * *} \\
(-4.038)\end{array}$ & $\begin{array}{c}-73.210^{* * *} \\
(-7.044)\end{array}$ \\
\hline Observations & 3296 & 2310 & 2739 & 557 & 1147 & 2149 \\
\hline Number of groups & 631 & 330 & 538 & 93 & 250 & 412 \\
\hline S.E. of regression & 12.997 & 13.427 & 12.127 & 16.290 & 12.388 & 12.932 \\
\hline R-Squared within & 0.249 & 0.246 & 0.288 & 0.179 & 0.282 & 0.253 \\
\hline $\operatorname{corr}\left(u_{-} \_\mathrm{i}, \mathrm{Xb}\right)$ & -0.660 & -0.683 & -0.618 & -0.590 & -0.727 & -0.688 \\
\hline rho & 0.483 & 0.432 & 0.504 & 0.301 & 0.538 & 0.529 \\
\hline F-test risk characteristics & $17.090^{* * *}$ & $13.946^{* * *}$ & $14.479^{* * *}$ & $4.807^{* * *}$ & $5.778^{* * *}$ & $16.186^{* * *}$ \\
\hline F-test time effects & $60.607^{* * *}$ & $43.338^{* * *}$ & $57.993^{* * *}$ & $9.538^{* * *}$ & $26.329 * * *$ & $41.177^{* * *}$ \\
\hline
\end{tabular}

$t$ statistics in parentheses
${ }^{*} p<0.10,{ }^{* *} p<0.05,{ }^{* * *} p<0.01$ 


\section{Table 16: Growth rate of customer deposits}

The table reports the fixed effects (within) regression results of the customer deposit growth rate w.r.t. bank risk characteristics. Estimators for the fixed effects and the time dummies are not reported in order to save space. t-statistics are in parentheses. Clustered standard errors are computed. F-tests for time effects and bank risk characteristics test the null hypothesis that these variables are jointly equal to zero.

\begin{tabular}{|c|c|c|c|c|c|c|}
\hline \multirow[b]{2}{*}{ Explanatory Variables } & \multicolumn{2}{|c|}{ Panel Structure } & \multicolumn{2}{|c|}{ West-/East Germany } & \multicolumn{2}{|c|}{ Bank Size } \\
\hline & Unbalanced & Balanced & West & East & Large & Small \\
\hline Lag(capital/assets $\cdot 100)$ & $\begin{array}{c}0.962^{* * *} \\
(3.333)\end{array}$ & $\begin{array}{c}0.683^{* *} \\
(2.132)\end{array}$ & $\begin{array}{c}0.911^{* * * *} \\
(2.727)\end{array}$ & $\begin{array}{l}1.151^{*} \\
(1.769)\end{array}$ & $\begin{array}{c}0.488 \\
(0.852)\end{array}$ & $\begin{array}{c}1.154^{* * * *} \\
(3.463)\end{array}$ \\
\hline Lag(risk expenditures/assets · 100) & $\begin{array}{l}-0.388^{*} \\
(-1.826)\end{array}$ & $\begin{array}{c}-0.218 \\
(-0.900)\end{array}$ & $\begin{array}{l}-0.350 \\
(-1.417)\end{array}$ & $\begin{array}{c}-0.318 \\
(-0.658)\end{array}$ & $\begin{array}{c}-0.317 \\
(-0.935)\end{array}$ & $\begin{array}{l}-0.510^{*} \\
(-1.867)\end{array}$ \\
\hline Lag(real estate and public loans/assets $\cdot 100)$ & $\begin{array}{l}0.053^{*} \\
(1.864)\end{array}$ & $\begin{array}{c}0.047 \\
(1.528)\end{array}$ & $\begin{array}{l}0.059^{*} \\
(1.837)\end{array}$ & $\begin{array}{c}-0.009 \\
(-0.146)\end{array}$ & $\begin{array}{c}0.041 \\
(0.878)\end{array}$ & $\begin{array}{l}0.061^{*} \\
(1.674)\end{array}$ \\
\hline Lag(personnel expenditures/assets $\cdot 100)$ & $\begin{array}{c}0.499 \\
(0.577)\end{array}$ & $\begin{array}{c}0.739 \\
(0.759)\end{array}$ & $\begin{array}{c}0.334 \\
(0.353)\end{array}$ & $\begin{array}{c}1.166 \\
(0.555)\end{array}$ & $\begin{array}{l}2.993^{*} \\
(1.744)\end{array}$ & $\begin{array}{c}-0.262 \\
(-0.259)\end{array}$ \\
\hline Lag(material expenditures/assets $\cdot 100)$ & $\begin{array}{c}0.318 \\
(0.439)\end{array}$ & $\begin{array}{c}-0.141 \\
(-0.172)\end{array}$ & $\begin{array}{c}0.263 \\
(0.302)\end{array}$ & $\begin{array}{c}0.379 \\
(0.261)\end{array}$ & $\begin{array}{c}-0.424 \\
(-0.253)\end{array}$ & $\begin{array}{c}0.959 \\
(1.134)\end{array}$ \\
\hline Lag(return/assets · 100) & $\begin{array}{c}0.998^{* * *} \\
(2.664)\end{array}$ & $\begin{array}{c}0.619 \\
(1.549)\end{array}$ & $\begin{array}{c}1.022^{* * * *} \\
(2.627)\end{array}$ & $\begin{array}{c}0.137 \\
(0.122)\end{array}$ & $\begin{array}{c}1.620^{* *} \\
(2.089)\end{array}$ & $\begin{array}{c}0.908^{* *} \\
(1.991)\end{array}$ \\
\hline Lag(cash/assets · 100) & $\begin{array}{c}0.015 \\
(0.129)\end{array}$ & $\begin{array}{c}-0.081 \\
(-0.821)\end{array}$ & $\begin{array}{c}0.010 \\
(0.072)\end{array}$ & $\begin{array}{c}0.060 \\
(0.383)\end{array}$ & $\begin{array}{c}-0.063 \\
(-0.495)\end{array}$ & $\begin{array}{c}0.104 \\
(0.628)\end{array}$ \\
\hline Constant & $\begin{array}{c}-5.507^{* * *} \\
(-3.649)\end{array}$ & $\begin{array}{c}-3.747^{* *} \\
(-2.292)\end{array}$ & $\begin{array}{c}-5.327^{* * *} \\
(-3.122)\end{array}$ & $\begin{array}{c}-4.974 \\
(-1.464)\end{array}$ & $\begin{array}{c}-5.704^{* *} \\
(-2.094)\end{array}$ & $\begin{array}{c}-6.292^{* * *} \\
(-3.282)\end{array}$ \\
\hline Observations & 3296 & 2310 & 2739 & 557 & 1147 & 2149 \\
\hline Number of groups & 631 & 330 & 538 & 93 & 250 & 412 \\
\hline S.E. of regression & 2.629 & 2.623 & 2.680 & 2.325 & 2.423 & 2.717 \\
\hline R-Squared within & 0.337 & 0.333 & 0.326 & 0.432 & 0.350 & 0.332 \\
\hline $\operatorname{corr}(\mathrm{u} \quad \mathrm{i}, \mathrm{Xb})$ & -0.244 & -0.192 & -0.205 & -0.132 & -0.220 & -0.294 \\
\hline rho - , we & 0.337 & 0.275 & 0.332 & 0.263 & 0.400 & 0.350 \\
\hline F-test risk characteristics & $4.161^{* * *}$ & $2.066^{* *}$ & $3.021^{* *}$ & 0.972 & $1.926^{*}$ & $3.321^{* * *}$ \\
\hline F-test time effects & $189.223^{* * *}$ & $149.473^{* * *}$ & $147.617^{* * *}$ & $50.260 * * *$ & $72.211^{* * *}$ & $117.382^{* * *}$ \\
\hline
\end{tabular}

$t$ statistics in parentheses
${ }^{*} p<0.10,{ }^{* *} p<0.05,{ }^{* * *} p<0.01$ 


\section{Table 17: Growth rate of securitized liabilities}

The table reports the fixed effects (within) regression results of the securitized liabilities growth rate w.r.t. bank risk characteristics. Estimators for the fixed effects and the time dummies are not reported in order to save space. t-statistics are in parentheses. Clustered standard errors are computed. F-tests for time effects and bank risk characteristics test the null hypothesis that these variables are jointly equal to zero.

\begin{tabular}{|c|c|c|c|c|c|c|}
\hline \multirow[b]{2}{*}{ Explanatory Variables } & \multicolumn{2}{|c|}{ Panel Structure } & \multicolumn{2}{|c|}{ West-/East Germany } & \multicolumn{2}{|c|}{ Bank Size } \\
\hline & Unbalanced & Balanced & West & East & Large & Small \\
\hline Lag(capital/assets · 100) & $\begin{array}{c}4.361 \\
(1.602)\end{array}$ & $\begin{array}{c}7.284^{* *} \\
(2.563)\end{array}$ & $\begin{array}{c}2.144 \\
(0.770)\end{array}$ & $\begin{array}{c}18.868^{* *} \\
(2.265)\end{array}$ & $\begin{array}{c}1.115 \\
(0.235)\end{array}$ & $\begin{array}{c}5.207 \\
(1.526)\end{array}$ \\
\hline Lag(risk expenditures/assets $\cdot 100$ ) & $\begin{array}{c}-2.570 \\
(-1.194)\end{array}$ & $\begin{array}{c}0.737 \\
(0.292)\end{array}$ & $\begin{array}{c}-2.489 \\
(-1.058)\end{array}$ & $\begin{array}{c}-2.053 \\
(-0.392)\end{array}$ & $\begin{array}{c}-0.247 \\
(-0.071)\end{array}$ & $\begin{array}{c}-4.000 \\
(-1.398)\end{array}$ \\
\hline Lag(real estate and public loans/assets $\cdot 100)$ & $\begin{array}{c}-0.021 \\
(-0.075)\end{array}$ & $\begin{array}{c}-0.210 \\
(-0.648)\end{array}$ & $\begin{array}{c}0.280 \\
(1.082)\end{array}$ & $\begin{array}{r}-2.219^{* *} \\
(-2.392)\end{array}$ & $\begin{array}{c}-0.013 \\
(-0.033)\end{array}$ & $\begin{array}{c}0.043 \\
(0.108)\end{array}$ \\
\hline Lag(personnel expenditures/assets $\cdot 100)$ & $\begin{array}{l}10.332 \\
(1.247)\end{array}$ & $\begin{array}{c}7.889 \\
(0.770)\end{array}$ & $\begin{array}{c}18.968^{* *} \\
(2.352)\end{array}$ & $\begin{array}{l}-41.269 \\
(-1.274)\end{array}$ & $\begin{array}{c}7.900 \\
(0.511)\end{array}$ & $\begin{array}{l}10.801 \\
(1.062)\end{array}$ \\
\hline $\operatorname{Lag}($ material expenditures/assets $\cdot 100)$ & $\begin{array}{c}4.054 \\
(0.556)\end{array}$ & $\begin{array}{c}-3.239 \\
(-0.322)\end{array}$ & $\begin{array}{l}-11.486 \\
(-1.633)\end{array}$ & $\begin{array}{l}30.439^{*} \\
(1.880)\end{array}$ & $\begin{array}{c}28.160^{* *} \\
(2.497)\end{array}$ & $\begin{array}{c}-6.655 \\
(-0.717)\end{array}$ \\
\hline Lag(return/assets · 100) & $\begin{array}{l}7.342^{*} \\
(1.727)\end{array}$ & $\begin{array}{l}1.036 \\
(0.304)\end{array}$ & $\begin{array}{c}6.247 \\
(1.434)\end{array}$ & $\begin{array}{c}1.634 \\
(0.144)\end{array}$ & $\begin{array}{c}23.055^{* * *} \\
(2.870)\end{array}$ & $\begin{array}{c}3.533 \\
(1.073)\end{array}$ \\
\hline $\operatorname{Lag}(\operatorname{cash} /$ assets $\cdot 100)$ & $\begin{array}{c}0.519 \\
(0.588)\end{array}$ & $\begin{array}{c}1.020 \\
(0.940)\end{array}$ & $\begin{array}{c}0.566 \\
(0.606)\end{array}$ & $\begin{array}{c}0.038 \\
(0.016)\end{array}$ & $\begin{array}{c}1.951 \\
(1.445)\end{array}$ & $\begin{array}{c}-0.988 \\
(-1.001)\end{array}$ \\
\hline Constant & $\begin{array}{c}-41.323^{* * *} \\
(-3.086) \\
\end{array}$ & $\begin{array}{c}-37.994^{* *} \\
(-2.447) \\
\end{array}$ & $\begin{array}{c}-42.906^{* * *} \\
(-3.038) \\
\end{array}$ & $\begin{array}{l}14.044 \\
(0.341) \\
\end{array}$ & $\begin{array}{c}-47.802^{* *} \\
(-2.136) \\
\end{array}$ & $\begin{array}{c}-36.657^{* *} \\
(-2.155) \\
\end{array}$ \\
\hline Observations & 2830 & 1938 & 2465 & 365 & 1107 & 1723 \\
\hline Number of groups & 577 & 295 & 505 & 72 & 248 & 360 \\
\hline S.E. of regression & 21.268 & 22.230 & 20.529 & 23.474 & 19.056 & 22.166 \\
\hline R-Squared within & 0.084 & 0.095 & 0.070 & 0.306 & 0.071 & 0.117 \\
\hline $\operatorname{corr}\left(u_{i}\right.$ i, $\left.\mathrm{Xb}\right)$ & -0.205 & -0.272 & -0.198 & -0.599 & -0.220 & -0.235 \\
\hline rho & 0.475 & 0.455 & 0.463 & 0.669 & 0.415 & 0.497 \\
\hline F-test risk characteristics & 1.673 & 1.579 & $2.074^{* *}$ & $3.238^{*}$ & $2.773^{* *}$ & 1.353 \\
\hline F-test time effects & $20.608^{* * *}$ & $17.840^{* * *}$ & $17.263^{* * *}$ & $7.544^{* * *}$ & $6.193^{* * *}$ & $20.251^{* * *}$ \\
\hline
\end{tabular}

${ }^{*} p<0.10,{ }^{* *} p<0.05,{ }^{* * *} p<0.01$ 


\section{Table 18: Growth rate of subordinated debt}

The table reports the fixed effects (within) regression results of the subordinated debt growth rate w.r.t. bank risk characteristics. Estimators for the fixed effects and the time dummies are not reported in order to save space. t-statistics are in parentheses. Clustered standard errors are computed. F-tests for time effects and bank risk characteristics test the null hypothesis that these variables are jointly equal to zero.

\begin{tabular}{|c|c|c|c|c|c|c|}
\hline \multirow[b]{2}{*}{ Explanatory Variables } & \multicolumn{2}{|c|}{ Panel Structure } & \multicolumn{2}{|c|}{ West-/East Germany } & \multicolumn{2}{|c|}{ Bank Size } \\
\hline & Unbalanced & Balanced & West & East & Large & Small \\
\hline Lag(capital/assets $\cdot 100)$ & $\begin{array}{c}1.436 \\
(0.610)\end{array}$ & $\begin{array}{c}2.178 \\
(0.805)\end{array}$ & $\begin{array}{c}1.519 \\
(0.535)\end{array}$ & $\begin{array}{c}-0.371 \\
(-0.077)\end{array}$ & $\begin{array}{c}5.552 \\
(1.182)\end{array}$ & $\begin{array}{c}1.187 \\
(0.429)\end{array}$ \\
\hline Lag(risk expenditures/assets $\cdot 100$ ) & $\begin{array}{c}-2.302 \\
(-1.319)\end{array}$ & $\begin{array}{c}-0.470 \\
(-0.223)\end{array}$ & $\begin{array}{c}-2.672 \\
(-1.274)\end{array}$ & $\begin{array}{c}-3.688 \\
(-1.217)\end{array}$ & $\begin{array}{c}-0.629 \\
(-0.212)\end{array}$ & $\begin{array}{c}-3.159 \\
(-1.436)\end{array}$ \\
\hline Lag(real estate and public loans/assets $\cdot 100)$ & $\begin{array}{c}-0.264 \\
(-1.055)\end{array}$ & $\begin{array}{c}-0.326 \\
(-1.126)\end{array}$ & $\begin{array}{c}-0.324 \\
(-1.148)\end{array}$ & $\begin{array}{c}0.193 \\
(0.344)\end{array}$ & $\begin{array}{l}-0.648^{*} \\
(-1.694)\end{array}$ & $\begin{array}{c}-0.019 \\
(-0.059)\end{array}$ \\
\hline Lag(personnel expenditures/assets $\cdot 100)$ & $\begin{array}{c}2.916 \\
(0.378)\end{array}$ & $\begin{array}{c}-4.677 \\
(-0.526)\end{array}$ & $\begin{array}{c}4.432 \\
(0.493)\end{array}$ & $\begin{array}{l}-15.559 \\
(-1.044)\end{array}$ & $\begin{array}{l}13.544 \\
(0.905)\end{array}$ & $\begin{array}{l}-2.654 \\
(-0.290)\end{array}$ \\
\hline Lag(material expenditures/assets $\cdot 100)$ & $\begin{array}{c}3.897 \\
(0.701)\end{array}$ & $\begin{array}{c}4.830 \\
(0.723)\end{array}$ & $\begin{array}{c}8.215 \\
(1.031)\end{array}$ & $\begin{array}{c}5.221 \\
(0.718)\end{array}$ & $\begin{array}{l}-14.012 \\
(-1.214)\end{array}$ & $\begin{array}{l}10.988^{*} \\
(1.736)\end{array}$ \\
\hline Lag(return/assets · 100) & $\begin{array}{c}3.351 \\
(1.329)\end{array}$ & $\begin{array}{c}2.692 \\
(0.877)\end{array}$ & $\begin{array}{c}4.311 \\
(1.447)\end{array}$ & $\begin{array}{c}5.727 \\
(0.864)\end{array}$ & $\begin{array}{c}-0.028 \\
(-0.004)\end{array}$ & $\begin{array}{c}2.801 \\
(1.068)\end{array}$ \\
\hline $\operatorname{Lag}(\operatorname{cash} /$ assets $\cdot 100)$ & $\begin{array}{c}-0.463 \\
(-0.590)\end{array}$ & $\begin{array}{c}-0.386 \\
(-0.457)\end{array}$ & $\begin{array}{c}0.112 \\
(0.118)\end{array}$ & $\begin{array}{l}-2.663^{*} \\
(-1.899)\end{array}$ & $\begin{array}{c}0.232 \\
(0.220)\end{array}$ & $\begin{array}{l}-1.043 \\
(-0.906)\end{array}$ \\
\hline Constant & $\begin{array}{c}-0.167 \\
(-0.015)\end{array}$ & $\begin{array}{c}8.125 \\
(0.658)\end{array}$ & $\begin{array}{c}-4.211 \\
(-0.334)\end{array}$ & $\begin{array}{l}16.537 \\
(0.730)\end{array}$ & $\begin{array}{c}-6.249 \\
(-0.336)\end{array}$ & $\begin{array}{c}-3.707 \\
(-0.271) \\
\end{array}$ \\
\hline Observations & 2743 & 1877 & 2217 & 526 & 993 & 1750 \\
\hline Number of groups & 552 & 282 & 460 & 92 & 228 & 353 \\
\hline S.E. of regression & 19.837 & 20.795 & 19.945 & 19.089 & 18.211 & 20.422 \\
\hline R-Squared within & 0.069 & 0.085 & 0.084 & 0.051 & 0.070 & 0.074 \\
\hline $\operatorname{corr}\left(u_{i} i, \mathrm{Xb}\right)$ & -0.146 & -0.155 & -0.193 & -0.100 & -0.422 & -0.119 \\
\hline rho - & 0.409 & 0.441 & 0.396 & 0.487 & 0.424 & 0.453 \\
\hline F-test risk characteristics & 0.695 & 0.552 & 0.849 & 1.260 & 0.849 & 0.805 \\
\hline F-test time effects & $15.226^{* * *}$ & $13.158^{* * *}$ & $15.955^{* * *}$ & $2.414^{* * *}$ & $6.266^{* * *}$ & $9.292^{* * *}$ \\
\hline
\end{tabular}

$t$ statistics in parentheses
${ }^{*} p<0.10,{ }^{* *} p<0.05,{ }^{* * *} p<0.01$ 


\section{References}

Baer, H. and Brewer, E., 1986, Uninsured deposit as a source of market discipline: Some new evidence. Economic Perspectives, 23-31.

Basel Committee on Banking Supervision, 2003, Markets for bank subordinated debt and equity in basel committee member countries. Technical Report 12, Bank for International Settlements.

Berger, A. N., 1991, Market discipline in banking. Proceedings of a conference on bank structure and competition. Federal Reserve Bank of Chicago.

Birchler, U. W. and Maechler, A. M., 2002, Do depositors discipline swiss banks? Research in Financial Services, 14, 243-275.

Board of Governors of the Federal Reserve System and U.S. Department of the Treasury, 2000, The feasability and desirability of mandatory subordinated debt, report to the congress, december.

Boot, A. W. and Greenbaum, S. I., 1993, Bank regulation, reputation and rents: Theory and policy implications. In C. Mayer and X. Vives, editors, Capital Markets and Financial Intermediation, 262-291. Cambridge University Press, Cambridge.

Cook, D. O. and Spellman, L. J., 1996, Firm and guarantor risk, risk contagion, and the interfirm spread among insured deposits. Journal of Financial and Quantitative Analysis, $31,265-281$.

Davenport, A. M. and McDill, K. M., 2006, The depositor behind the discipline: A micro-level case study of Hamilton bank. Journal of Financial Services Research, 30, 93-109.

Demirgüç-Kunt, A. and Huizinga, H., 2004, Market discipline and deposit insurance. Journal of Monetary Economics, 51, 375-399.

Demirgüç-Kunt, A. and Kane, E. J., 2002, Deposit insurance around the globe: Where does it work? Journal of Economic Perspectives, 16, 175-195. 
Demirgüç-Kunt, A. and Kane, E. J., 2003, Deposit insurance: Handle with care. Technical Report 227, Central Bank of Chile.

Demirgüç-Kunt, A., Karacaovali, B., and Laeven, L., 2005, Deposit insurance around the world: a comprehensive database. Technical Report 3628, June 2005, World Bank Policy Research Working Paper.

Deutsche Bundesbank, 2007a, Banking statistics - September 2007. Frankfurt am Main.

Deutsche Bundesbank, 2007b, Time series database, balance sheet total, time series keys OU0308, OU0748, OU0824, OU1024, OU1074, OU1124, OU1174. Frankfurt am Main. http://www.bundesbank.de/statistik/statistik_zeitreihen.en.php (2007-12-08).

Deutsche Bundesbank, 2007c, Time series database, money market rates reported by Frankfurt banks / twelve-month funds / monthly average, time series key SU0253. Frankfurt am Main. http://www.bundesbank.de/statistik/statistik_zeitreihen.en.php (2007-12-08).

Deutsche Bundesbank, 2007d, Time series database, number of reporting credit institutions, time series keys OU0331, OU0748, OU0823, OU1023, OU1073, OU1123, OU1173. Frankfurt am Main. http://www.bundesbank.de/statistik/statistik_zeitreihen.en.php (2007-12-08).

Diamond, D. W. and Dybvig, P. H., 1983, Bank runs, deposit insurance, and liquidity. Journal of Political Economy, 91, 401-419.

Ellis, D. and Flannery, M., 1992, Does the debt market assess large banks' risk?: Time series evidence from money center CDs. Journal of Monetary Economics, 30, 481-502.

Flannery, M. J., 1998, Using market information in prudential bank supervision: A review of the U.S. empirical evidence. Journal of Money, Credit, and Banking, 30, 273-305.

Franks, J., de Servigny, A., and Davydenko, S., 2004, A comparative analysis of the recovery process and recovery rates for private companies in the U.K., France and Germany.

Frolov, M., 2004, Deposit insurance and its design: A literature review. Technical Report 2004-004, Keio University Market Quality Research Project (KUMQRP) Discussion Paper Series. 
Fueda, I. and Konishi, M., 2007, Depositors' response to deposit insurance reforms: Evidence from Japan, 1990-2005. Journal of Financial Services Research, 31, 101-122.

Furlong, F. T., 1984, A view on deposit insurance coverage. Economic Review, Federal Reserve Bank of San Francisco, 2, 31-38.

Gilbert, R. A., 1990, Market discipline of bank risk: Theory and evidence. Federal Reserce Bank of St. Louis Review, 72, 3-18.

Günther, H.-G., 2006, Die Sparkassen im heutigen Gebiet des Ostdeutschen Sparkassenverbandes seit 1945. In Wissenschaftsförderung der Sparkassen-Finanzgruppe e.V., editor, Regionalgeschichte der Sparkassen-Finanzgruppe, Band 1, 231-263. Deutscher Sparkassenverlag, Stuttgart.

Gräbener, T., 2008, Die Marktdisziplinierung der Kreditinstitute. Fritz Knapp, Frankfurt am Main.

Hackethal, A., 2004, German banks and banking structure. In J. P. Krahnen and R. H. Schmidt, editors, The German Financial System, 71-105. Oxford University Press, New York.

Hamilton, L. C., 2006, Statistics with STATA, Updated for Version 9. Thomson Brooks/Cole, Duxbury.

Hovakimian, A., Kane, E. J., and Laeven, L., 2003, How country and safety-net characteristics affect bank risk-shifting. Journal of Financial Services Research, 23, 177-204.

Ioannidou, V. P. and de Dreu, J., 2006, The impact of explicit deposit insurance on market discipline. Technical Report 2006-05, Tilburg University, Center for Economic Research.

Kobayashi, A. and Bremer, M., 2007, The depositor discipline hypothesis - The transition to an interaction effect. Japanese Journal of Administrative Science, 20, 13-26.

Koetter, M., Nestmann, T., Stolz, S., and Wedow, M., 2006, Still overbanked and unprofitable? Two decades of German banking. Kredit und Kapital, 39, 497-511.

Maechler, A. M. and McDill, K. M., 2006, Dynamic depositor discipline in US banks. Journal of Banking and Finance, 30, 1871-1898. 
Martinez Peria, M. and Schmukler, S. L., 2001, Do depositors punish banks for bad behavior? Market discipline, deposit insurance, and banking crises. Journal of Finance, 56, 1029-1051.

Merton, R. C., 1977, An analytic derivation of the cost of deposit insurance and loan guarantees. An application of modern option pricing theory. Journal of Banking and Finance, 1, 3-11.

Moormann, D. and Schnitzler, R., 2007, Rangliste der Sparkassen 2006 - Wirtschaftliche Erholung gab dem Bilanzwachstum Impulse. Betriebswirtschaftliche Blätter, 56, 406-415.

Park, S., 1995, Market discipline by depositors: Evidence from reduced-form equations. The Quarterly Review of Economics and Finance, 35, 497-514.

Park, S. and Peristiani, S., 1998, Market discipline by thrift depositors. Journal of Money, Credit, and Banking, 30, 347-364.

Stock, J. and Watson, M. W., 2007, Introduction to Econometrics. Pearson Education Inc., Boston, 2nd edition.

Wysocki, J. and Günther, H.-G., 1996, Geschichte der Sparkassen in der DDR 1945 bis 1990. Deutscher Sparkassenverlag, Stuttgart. 